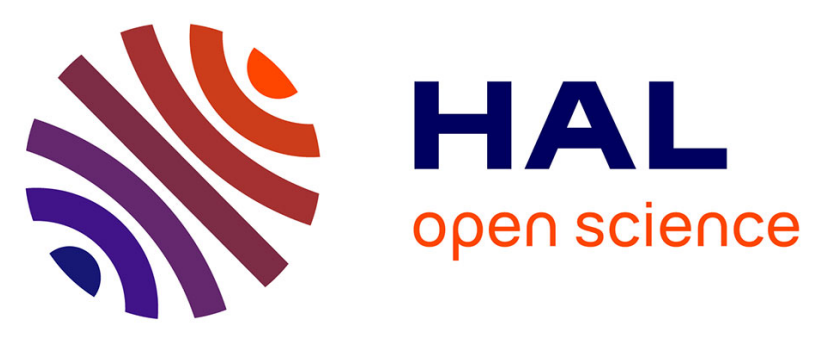

\title{
Long-term nitrogen dynamics in various catch crop scenarios: Test and simulations with STICS model in a temperate climate
}

Jean Constantin, Nicolas Beaudoin, Marie Launay, Jérôme Duval, Bruno B. Mary

\section{To cite this version:}

Jean Constantin, Nicolas Beaudoin, Marie Launay, Jérôme Duval, Bruno B. Mary. Long-term nitrogen dynamics in various catch crop scenarios: Test and simulations with STICS model in a temperate climate. Agriculture, Ecosystems and Environment, 2012, 147, pp.36-46. 10.1016/j.agee.2011.06.006 . hal-02650637

\section{HAL Id: hal-02650637 \\ https://hal.inrae.fr/hal-02650637}

Submitted on 29 May 2020

HAL is a multi-disciplinary open access archive for the deposit and dissemination of scientific research documents, whether they are published or not. The documents may come from teaching and research institutions in France or abroad, or from public or private research centers.
L'archive ouverte pluridisciplinaire HAL, est destinée au dépôt et à la diffusion de documents scientifiques de niveau recherche, publiés ou non, émanant des établissements d'enseignement et de recherche français ou étrangers, des laboratoires publics ou privés. 
Version définitive du manuscrit publié dans / Final version of the manuscript published in : Agriculture Ecosystems and Environment, 2011, In Press, DOI: 10.1016/j.agee.2011.06.

Long-term nitrogen dynamics in various catch crop scenarios: test and simulations with STICS model in a temperate climate

$5 \quad{ }^{1}$ INRA Agro-Impact, Site de Laon, Pôle du Griffon, 02000 Barenton-Bugny, France

$6 \quad{ }^{2}$ INRA Agroclim, Domaine Saint Paul, Site Agroparc 84914 Avignon Cedex 9, France

8 Corresponding author: Nicolas Beaudoin

14 Keywords: cover crop, nitrate, leaching, mineralization, sequestration, fertilisation, climate change, 15 modelling, simulation. 
Version définitive du manuscrit publié dans / Final version of the manuscript published in : Agriculture Ecosystems and Environment, 2011, In Press, DOI: 10.1016/j.agee.2011.06.

16

17 The long term effects of repeated catch crops on $\mathrm{N}$ dynamics in arable farming were assessed using

18 mid-term experiments and long-term simulations. The soil-crop model STICS (v6.9) was tested

19 against a database provided by three experiments (13-17 years) carried out in Northern France,

20 including treatments with or without repeated catch crops. STICS performance was checked for

21 crop biomass, $\mathrm{N}$ uptake, soil water content and mineral $\mathrm{N}$ at harvest of main crops, drained water, $\mathrm{N}$

22 leaching and mineralization rates. The model satisfactorily reproduced these variables, except for

23 soil mineral $\mathrm{N}$ and $\mathrm{N}$ leached at one site. $\mathrm{N}$ leached was predicted with a slight bias, between -3 and

$24+7 \mathrm{~kg} \mathrm{~N} \mathrm{ha}^{-1} \mathrm{yr}^{-1}$, and soil $\mathrm{N}$ mineralized was simulated with a bias lower than $7 \mathrm{~kg} \mathrm{~N} \mathrm{ha}^{-1} \mathrm{yr}^{-1}$. The

25 model simulated correctly the $\mathrm{N}$ uptake by catch crops and the kinetics of extra $\mathrm{N}$ mineralization

26 due to catch crops. Seven scenarios varying in the presence of catch crops, fertilization rate and

27 climate were simulated on long-term (60 years); their effects on $\mathrm{N}$ uptake, soil $\mathrm{N}$ storage, $\mathrm{N}$

28 mineralization and nitrate leaching were compared by difference with a control scenario. Repeated

29 catch crops lead to reduce $\mathrm{N}$ leaching, sequester organic $\mathrm{N}$ and increase $\mathrm{N}$ mineralization. The

30 model indicated that the sequestered $\mathrm{N}$ reached a maximum of 430-750 kg N ha ${ }^{-1}$ after 23-45 years

31 depending on site. The extra-mineralization due to catch crops progressively increased up to 38-65

$32 \mathrm{~kg} \mathrm{~N} \mathrm{ha}^{-1} \mathrm{yr}^{-1}$. A strategy of constant $\mathrm{N}$ fertilizer rate resulted in raising the $\mathrm{N}$ uptake of main crops

33 and slowing down the abatement of nitrate leaching. Conversely, when $\mathrm{N}$ fertilization rates were

34 reduced by 20-24 $\mathrm{kg} \mathrm{N} \mathrm{ha}^{-1} \mathrm{yr}^{-1}$, crop production remained stable and catch crops reduced $\mathrm{N}$

35 leaching on the long term by 33-55\%. Therefore catch crop is a promising technique for controlling

36 the $\mathrm{N}$ cascade. 


\section{Introduction}

38 The last application of the European Nitrate Directive (91/676/EC) lead governments to stipulate

39 that catch crops must be grown in fallow periods to diminish the risk of nitrogen leaching. It is

40 therefore important to better assess the efficiency and sustainability of this practice in various pedo-

41 climatic contexts and cropping systems. The short-term effects of catch crops on $\mathrm{N}$ leaching and

42 balance are well known, but all impacts of the practice cannot be determined at this time scale. A

43 marked increase in N mineralization with catch crops has been reported in several studies (Schröder

44 et al., 1996; Torstensson and Aronsson, 2000). In addition, the higher soil organic matter found after

45 several years of repeated catch crops (Blombäck et al., 2003; Berntsen et al., 2006) indicates that

46 the long-term effects of catch crops could be different from those observed after one or two years.

47 The change in mineralization, which is partly due to increased soil organic matter (SOM), could

48 result in increased $\mathrm{N}$ uptake by main crops after 13 to 24 years (Hansen et al., 2000; Constantin et

49 al., 2011). However, the duration of these experiments was not long enough to determine the level

50 and timing of steady state conditions, particularly on mineralization and organic $\mathrm{N}$ in soil. These

51 authors suggested to adjust the $\mathrm{N}$ fertiliser rate in the long term in order to avoid the risk of

52 increasing nitrate leaching due to extra $\mathrm{N}$ mineralization from catch crop residues. It has also been

53 shown that $\mathrm{N}$ leaching was enhanced in fields having received repeated crops during several years

54 after catch crops are abandoned (Thomsen and Christensen, 1999), but the duration of this effect is

55 not well known.

56 Crop models can be useful tools in illustrating and predicting the long-term effects of agricultural

57 practices on the $\mathrm{N}$ cycle in various conditions. Models can help determine $\mathrm{N}$ mitigation, leaching or

58 turnover in soil as a result of improved agricultural practices such as catch crops (Aronsson and

59 Tortensson, 1998; Blombäck et al., 2003). However these models must be first tested and verified

60 against different experimental datasets in time and space in order to ensure their efficiency to

61 correctly simulate reality. To predict changes in a given agrosystem, models must be dynamic and 
62 integrate the impacts of climate, soil properties, agricultural techniques and various crops, including

63 catch crops. STICS is a soil-crop model that simulates crop development and environmental

64 impacts, such as N leaching and sequestration (Brisson et al., 1998; Brisson et al., 2008). It has been

65 tested in annual simulations for a number of crops (e.g. Brisson et al., 2003) and calibrated to

66 simulate $\mathrm{C}$ and $\mathrm{N}$ dynamics during decomposition of various mature and young (catch) crops

67 residues (Nicolardot et al., 2001; Justes et al., 2009). STICS predictions of soil net N mineralization

68 kinetics in the short term are reasonably accurate, but the model may underestimate soil organic

69 carbon in the long term (Gabrielle et al., 2002). STICS was evaluated over the medium-term (8

70 years) in a small catchment in northern France for varied soils and crops including catch crops and

71 was able to correctly simulate $\mathrm{N}$ uptake by crops, $\mathrm{N}$ content in crop residues and soil mineral $\mathrm{N}$ at

72 harvest and in late autumn (Beaudoin et al., 2008). However, longer term tests are needed to

73 determine the ability of the model to predict long-term changes in $\mathrm{N}$ mineralization and storage in

74 soil as a function of alternative agricultural practices such as catch crops and in response to climate 75 change.

76 The objectives of this study were: i) to evaluate the performance of the STICS model in long-term 77 prediction of $\mathrm{N}$ balance and outputs by crop and leaching; ii) to determine the ability of STICS to 78 simulate $\mathrm{N}$ turnover in soil (sequestration and mineralization), particularly with continuous use of 79 catch crops; and iii) to test longer-term scenarios with and without global warming to determine 80 whether steady state could be reached and to analyse the effects of continuing or abandoning catch 81 crops.

\section{3. Materials and methods}

\section{3.1. Experimental databases}

84 Two databases, called "reference database” and "catch crop database”, were used to calibrate and 85 evaluate the model. The reference database is an external database used to calibrate crop 86 parameters. It compiles several experiments with various crop species, including main crops (winter 
87 wheat, sugar beet, spring peas, spring barley, maize) and catch crops (mustard, ryegrass), as

88 described by Beaudoin et al. (2008). It contains data on crop aerial biomass, grain yield, $\mathrm{N}$ in aerial

89 biomass and harvested organs, leaf area index, rooting depth, soil water and mineral $\mathrm{N}$ contents in 3

90 to 4 layers down to 90 or $120 \mathrm{~cm}$. The catch crop database gathers experimental data obtained on

91 three long-term (13-17 years) field experiments in Northern France reported by Constantin et al.

92 (2010). The three experiments included a treatment with (CC) or without (NoCC) catch crop; an

93 additional $\mathrm{N}$ fertiliser treatment was tested on one site until 2003: reduced rate ( $\left.\mathrm{N}^{-}\right)$versus

94 conventional rate $(\mathrm{N})$. Crop rotation and $\mathrm{N}$ inputs differed between sites, as did catch crop species

95 and their frequency (Table 1). Biomass production and $\mathrm{N}$ content of main crops and catch crops

96 were measured every year. Soil mineral N (SMN) and water content (SWC) were measured over

97 90-110 cm depth three times per year: at harvest, end of autumn and mid-winter. Drained water was

98 measured in lysimeters, which were managed similarly to the field plots. Nitrate concentration was

99 measured in porous cups installed in all treatments at 90-110 cm depth: 7 porous cups were pooled

100 to make one replicate and were sampled 3 to 10 times per year according to drainage intensity.

101 These methods have been shown to be relevant to assess free drainage and nitrate leaching (Webster

102 et al., 1993). N leaching was calculated using the trapezoidal method (Lord and Shepherd, 1993),

103 which consists in interpolating drainage between two dates of measurement in the porous cups.

104 Fertiliser use efficiency was measured every year in two sites by the difference method (between

105 fertilized and unfertilized plots), and also in all sites during the last two years using ${ }^{15} \mathrm{~N}$ labelled

106 fertilizers. In situ net $\mathrm{N}$ mineralization was calculated using soil $\mathrm{N}$ mineral balance, which takes

107 into account $\mathrm{N}$ inputs (fertilization, atmospheric deposition, symbiotic fixation), $\mathrm{N}$ outputs

108 (harvested $\mathrm{N}$, leaching, gaseous losses) and SMN variation during the calculation period, according

109 to the procedure described by Constantin et al. (2011). Organic N and C stocks in soil were

110 measured at the end of the experiment at all sites. The catch crop database was managed for the

111 three sites using the open source software Postgre-SQL (www.postgresql.org). Data on soil 
112 characteristics, climate variables, crops, agricultural techniques, $\mathrm{N}$ fertilisation and all measured

113 data were recorded and an interface was created to allow the STICS model to be run automatically.

114 Half of the catch crop database was used to recalibrate a few crop and soil parameters when model

115 performance was unsatisfactory; the other half was used for model evaluation (Confalonieri et al., 116 2009).

\section{3.2. Overview of STICS model}

119 The soil crop model STICS is a dynamic model that simulates $\mathrm{C}, \mathrm{N}$ and water cycles. It is a one120 dimensional model with a daily time step, which takes into account soil characteristics, climate and 121 agricultural practices (Brisson et al., 2008). The potential development stages, leaf growth and 122 growth rate of a given crop depend on photothermal units and solar radiation. The effective crop 123 growth rate is affected by water and nitrogen stresses and atmospheric $\mathrm{CO}_{2}$ concentration. The soil 124 is divided into several layers with specific characteristics such as water content at field capacity, 125 permanent wilting point and bulk density. Residue decomposition in soil is simulated using three compartments: the fresh organic matter, the microbial biomass and humified organic matter, the last compartment being composed of an active and an inert fraction. $\mathrm{N}$ and $\mathrm{C}$ fluxes between these compartments depend on their $\mathrm{C}: \mathrm{N}$ ratio, soil temperature and water content, and four parameters: the humification constant, the decomposition rate constant of the residues, the decay rate of the microbial biomass and the assimilation yield of residue-C by the microbial biomass (Nicolardot et al., 2001). The first two parameters depend on C:N ratio of residues while the last two do not. When mineral $\mathrm{N}$ is exhausted in the soil, the decomposition rate of organic residues is reduced, the C: $\mathrm{N}$ 133 ratio of microbial biomass increases and the proportion of humified $\mathrm{N}$ is reduced (Giacomini et al., 134 2007). Model parameterization of mature and catch crops residues was made using a large dataset 135 of laboratory incubations (Justes et al., 2009). The $\mathrm{N}$ mineralized from humified organic matter 136 depends on the potential mineralization rate of the soil, which depends on clay, $\mathrm{CaCO}_{3}$ and organic 
$137 \mathrm{~N}$ contents in the biologically active layer, and the temperature and moisture conditions occurring in

138 this layer. STICS also simulates the gaseous losses (volatilisation and denitrification) derived from 139 fertilizer. They were simulated at the same level in the treatments with and without catch crops; this 140 result is consistent with the findings of Constantin et al. (2010).

\section{3.3. Inputs and calibration of the STICS model}

142 The models inputs concerning crop management and climate are available in the catch crop 143 database since they were routinely recorded. The soil characteristics of each site used in STICS are 144 shown at Table 2. The bulk density, the initial soil organic C content and C: $\mathrm{N}$ ratio of the soil were 145 set at the values measured in 2007. The water contents at field capacity $\left(W_{F C}\right)$ and wilting point $146\left(W_{W P}\right)$ were estimated using frequency analysis of measured water contents over the whole 147 experimental period (13-17 years). $W_{F C}$ is defined as "the water content held in soil after excess 148 water has drained away, which usually takes place within 2-3 days after a rain" (Hénin et al., 1969). 149 In our experiments, water contents were never measured during rainy days, so that $W_{F C}$ was 150 calculated as the mean of the highest values (first decile) of water contents measured in mid-winter. $151 W_{W P}$ was calculated as the mean of the lowest values (third centile) of the water contents measured

152 at summer harvests. The results compare favourably with those obtained with pedotransfer 153 functions (PDF): the mean value of $W_{W P}$ differed by $7 \mathrm{~g} \mathrm{~kg}^{-1}$ soil from the PDF function of Wösten 154 et al. (2001); $W_{F C}$ was greater than PDF (obtained at $-10 \mathrm{kPa}$ ) by $27 \mathrm{~g} \mathrm{~kg}^{-1}$, but $W_{F C}$ is known to be 155 highly dependent on soil structure and does not correspond to a constant water potential value (e.g. 156 Wösten et al., 2001). The depth of the biologically active layer ('mineralization depth') was 157 assumed to be $10 \%$ greater than the ploughing depth (Brisson et al., 2008). Using this rule, 158 Beaudoin et al. (2008) were able to simulate the $\mathrm{N}$ mineralization kinetics and organic matter 159 evolution of a permanent bare soil in a lysimeter.

160 The first step of calibration consisted in model calibration and evaluation against the independent 161 reference database. The model used in this paper (STICS version 6.9) had been previously 
162 calibrated and validated on the reference database for all crops grown at the three study sites, except

163 for radish. An additional parameterisation of spring barley was made on an additional independent 164 database. The model was then evaluated against the catch crop database. If necessary, a second 165 calibration was realized by adjusting a few crop and soil parameters against half of the catch crop 166 database (dataset without catch crops), using annual or continuous (over 13-17 years) simulations. 167 Annual simulations involved resetting SMN and SWC every year at harvest of main crops using the 168 observed values, while the model was initialised only once in continuous simulations and 169 simulations were run over 13-17 years. The calibration was applied when either the crop (biomass or N uptake) or soil variables (SMN or SWC) were not satisfactorily simulated by the model. Three

171 parameters were calibrated using annual simulations: the maximal rooting depth, the lifespan of

172 leaves, and the potential of fertilizer loss which influences the $\mathrm{N}$ use efficiency of fertilizer. For 173 these annual simulations, the calibration method consisted in minimizing the sum of squared errors 174 between observed and simulated values by the simplex method using the software package 175 OptimiSTICS (Wallach et al., 2011). Continuous simulations were used to calibrate two other soil 176 parameters: the initial organic $\mathrm{N}$ content (which was not measured) and the active fraction of 177 humified organic matter, in order to correctly simulate the soil organic $\mathrm{N}$ and $\mathrm{N}$ mineralization 178 kinetics observed in the field. A trial-error method was used for this calibration step. The objective 179 was to mimic as well as possible $\mathrm{N}$ uptake, mineralization and leaching in control treatments 180 (without catch crops).

\section{3.4. Evaluation of STICS model performance}

182 Three statistical criteria were used to evaluate the performance of the model: the root mean square 183 error (RMSE), the mean deviation (MD) and the model efficiency (EF), calculated as follows: 


$$
R M S E=\sqrt{\frac{1}{n} \sum_{i=1}^{n}\left(S_{i}-O_{i}\right)^{2}}
$$

$$
M D=\frac{1}{n} \sum_{i=1}^{n}\left(S_{i}-O_{i}\right)
$$

$$
E F=\frac{\sum_{i=1}^{n}\left(O_{i}-\bar{O}\right)^{2}-\sum_{i=1}^{n}\left(S_{i}-O_{i}\right)^{2}}{\sum_{i=1}^{n}\left(O_{i}-\bar{O}\right)^{2}}
$$

185 where $\mathrm{n}$ is the number of observations, $S_{i}$ and $O_{i}$ are the simulated and observed values respectively 186 and $\bar{O}$ is the mean value of observed data. The RMSE provides the model prediction error, while the $187 M D$ gives the bias of the model. The $E F$ estimates the model performance relative to the experimental mean (Nash and Sutcliffe, 1970). An $E F$ value close to zero indicates that the simulation does not perform better than a constant model equal to the mean of observed data. The combination of these indices gives a good overview of the model accuracy.

191 The mean effect of the improved practices (i.e. CC and $\mathrm{N}^{-}$) was obtained by difference with the 192 conventional practices (i.e. NoCC and N). The cumulative "extra mineralization" and leaching due 193 to catch crops was obtained by difference with the control treatment (CC - NoCC). At Thibie, it was 194 averaged between the fertilisation rate treatments ( $\mathrm{N}$ and $\mathrm{N}-$ ) because there was no significant 195 interaction between the two factors (Constantin et al., 2010).

\subsection{Catch crop management scenarios}

197 The model was used to simulate various scenarios in the long term. Simulations were performed 198 over 60 years (1990-2050), which include the first years of observations and the following 45 years.

199 The crop rotation and agricultural management were assumed to remain constant and similar to 200 those observed during the first 15 years. At Thibie, the initial rotation (sugarbeet - spring pea 201 winter wheat) was simulated throughout and the introduction of spring barley after 13 years was not 202 considered. Seven scenarios (S0-S6) were simulated, varying in the presence and frequency of catch 
203 crops, $\mathrm{N}$ fertilisation rate and climate (Table 3). The reference scenarios, S0 and S1, considered no

204 catch crop and standard fertilisation combined with constant or changing climate, respectively. Scenarios S2 and S3 included repeated catch crops during 60 years and standard fertilisation 206 without and with climate change, respectively. Scenario S4 considered a lower frequency of catch 207 crop establishment (once every three years at Boigneville and Thibie and once every four years at 208 Kerlavic) under changing climate and standard fertilisation. Scenario S5 simulated repeated catch 209 crops, climate change and a reduction in fertiliser rate after 15 years. The fertiliser dose was 210 decreased so that the simulated crop biomass in the treatment with catch crops remained equal to 211 that simulated for the control treatment (without catch crops), with a 3\% tolerance. Scenario S6 212 considered constant fertilisation and climate change, but with abandonment of catch crops after 15 213 years.

214 Two climate series were built for each site by considering constant climate or climate change. The 215 first series was built using random sampling of the 13-17 climatic years of experiment to constitute 216 a 60-year scenario. The second series, taking into account climate change, was made using the A1B 217 scenario (IPCC Special Report on Emissions Scenarios). It is based on extrapolating the actual 218 climate data of our experimental period using the A1B climate scenario, which considers that the 219 mean world temperature will increase between 2.5 and $3.5^{\circ} \mathrm{C}$ by 2100 . This scenario was applied to 220 each site using the statistical error correction proposed by Déqué (2007). It predicts that mean 221 temperature will increase by $\sim 0.8-1.0^{\circ} \mathrm{C}$ by 2050 . Annual rainfall would decrease at Kerlavic by $222125 \mathrm{~mm}$ (with a marked decrease in spring and summer), but would not change much at Boigneville 223 and Thibie $(-23$ and $+24 \mathrm{~mm})$. The change in $\mathrm{CO}_{2}$ concentration in the atmosphere was not 224 simulated continuously, but a constant concentration of $450 \mathrm{ppm}$ was assumed over the 60 year 225 period. This corresponds to the average of the present $\mathrm{CO}_{2}$ concentration and the expected value in 2262050. 


\section{4. Results}

\section{4.1. Model calibration}

229 The statistics of the model evaluation against the reference database for the crops involved in our 230 study are given at Table 4. All results are available on the STICS website. The model efficiency was 231 greater than 0.50 for $80 \%$ of crops and variables. The prediction of soil water contents (throughout 232 the year) was satisfactory in all situations. Mineral N contents were also well simulated except for 233 spring pea and maize. Crop biomass was satisfactorily predicted as well as aerial $\mathrm{N}$ uptake. The 234 poorest agreement between observed and simulated values was for harvested biomass. The model 235 evaluation of the catch crop database was not as good, so that a calibration was made against the 236 calibration dataset (Table 5). The maximal rooting depths were slightly reduced, particularly at 237 Kerlavic, in order to account for local soil conditions. The potential of fertilizer N loss which 238 determines the denitrification losses derived from fertilizer was increased at Kerlavic in order to 239 properly mimic the fertiliser use efficiency (which decreased from 66 to 62\%), while it was well 240 simulated on average at the two other sites. This specific calibration relies on the assumption that 241 the higher rainfall at Kerlavic favoured the denitrification process. The lifespan of leaves for winter 242 wheat, mustard, radish and ryegrass was decreased by 100, 60, 50 and 60 days respectively, to 243 better simulate aerial biomass of these crops which was systematically overestimated by the model. 244 The fitted values of initial organic N were close to those measured in 2007 at Boigneville and 245 Thibie, suggesting that the stocks were more or less at steady state. This result was not surprising 246 because the previous land use at these two sites was arable cropping with constant management. At 247 Kerlavic, where the previous land use was grassland, organic N decreased over time and was higher 248 at the beginning (calibrated at $3.20 \mathrm{~g} \mathrm{~kg}^{-1}$ ) than in 2007 (measured at $2.78 \mathrm{~g} \mathrm{~kg}^{-1}$ ). Finally, the active 249 fraction had to be increased from 35 to $44 \%$ of total SOM at Boigneville and to $60 \%$ at Kerlavic in 250 order to allow good simulation of net $\mathrm{N}$ mineralization and final $\mathrm{N}$ stock.

\section{4.2. Model evaluation}


Version définitive du manuscrit publié dans / Final version of the manuscript published in : Agriculture Ecosystems and Environment, 2011, In Press, DOI: 10.1016/j.agee.2011.06.

252

253

254

255

256

257

258

259

260

261

262

263

264

265

266

267

268

269

270

271

272

273

274

275

276

\subsubsection{Evaluation on crop and soil variables}

STICS performance was evaluated in continuous simulations against the catch crop database. The model could simulate well the soil water contents both in the reference database and the catch crop database (Figure 1). However the predictions were better in the reference database which showed a larger variance and a better efficiency. Table 6 summarizes STICS performance for the catch crop database. It shows that the quality of fit was about the same for the calibration and validation datasets. SWC at harvest was well predicted, except at Kerlavic where it was overestimated $(M D=$ 23-35 mm) particularly at harvest of winter wheat. SMN content at harvest was slightly overestimated on average (in spite of a good prediction of net mineralization, see further) and the model could not reproduce its variability. The model correctly simulated the aerial biomass of main crops and catch crops at Boigneville and Thibie $(E F=0.72-0.92)$, as well as the harvested biomass. At Kerlavic, the lower efficiency was associated with a large overestimation of wheat biomass, which could be due to limiting factors not taken into account by the model. The total $\mathrm{N}$ uptake was well simulated on all sites $(E F=0.41-0.90)$ without any bias; harvested $\mathrm{N}$ was correctly predicted except at Boigneville where it was underestimated (mean $M D=-20 \mathrm{~kg} \mathrm{ha}^{-1}$ ). STICS could also correctly simulate drainage and leaching, although the amount of drained water was slightly overestimated on all sites (by 10-20\%) and leached $\mathrm{N}$ overestimated (by about 25\%) at Boigneville. The variability of both variables was well mimicked by the model (positive efficiency), except for $\mathrm{N}$ leached at Boigneville.

\subsubsection{Ability to reproduce the effect of agricultural practices}

The effect of agricultural practices on $\mathrm{N}$ uptake and $\mathrm{N}$ leaching was calculated by difference between paired treatments: with $v s$ without catch crops or reduced vs standard fertilisation (Table 7). The two practices had contrasted impacts: catch crops exerted a small effect on $\mathrm{N}$ uptake and a strong effect on leached $\mathrm{N}$ whereas the opposite occurred for the reduction of fertilization. The model was able to satisfactorily predict these effects: model efficiency was 0.67 and 0.55 
277 respectively. The other variables of interest were soil $\mathrm{N}$ mineralized and organic $\mathrm{N}$ content. The

278 kinetics of net mineralization was well reproduced at all sites, with a slight underestimation at 279 Thibie (Figure 2). The mean difference between observed and simulated values of annual 280 mineralization was $-1,-2$ and $+7 \mathrm{~kg} \mathrm{~N} \mathrm{ha}^{-1} \mathrm{yr}^{-1}$ at Boigneville, Thibie and Kerlavic, respectively. 281 The dynamics of extra $\mathrm{N}$ mineralization due to catch crops (i.e. the difference between CC and 282 NoCC treatments) differed between sites for both observed and simulated data (Figure 4). At 283 Boigneville, the model underestimated the net release of $\mathrm{N}$ due to catch crops (white mustard) 284 during the first years and gave satisfactory predictions thereafter. This underestimation was 285 probably due to the fact that the predicted C:N ratio of mustard residues was greater than that 286 observed, inducing a smaller release of mineral $\mathrm{N}$ in the months following catch crop destruction. 287 The extra mineralization due to radish was slightly overestimated after 12-15 years at Thibie, 288 whereas the mineralization due to ryegrass was well simulated over time at Kerlavic, with $\mathrm{N}$ 289 immobilisation in the first years followed by net $\mathrm{N}$ release. The simulated organic $\mathrm{N}$ stocks in soil at 290 the end of experiments (13-17 years) were rather close to those observed in the field (Figure 3). The $291 \mathrm{~N}$ sequestered due to catch crops varied from 162 to $351 \mathrm{~kg} \mathrm{~N} \mathrm{ha}^{-1}$. It was slightly overestimated by 292 the model, but predictions remained within the confidence interval of measurements. The effect of 293 reduced fertilisation, mainly due to a reduction in $\mathrm{C}$ and $\mathrm{N}$ returns to the soil, was well predicted by 294 the model. Finally, the model appeared to give satisfactory prediction of the effects of catch crops 295 and reduced fertilisation on $\mathrm{N}$ uptake, leaching, mineralization and sequestration; despite a small 296 underestimation of the positive effect of catch crops on $\mathrm{N}$ uptake, it could be used for simulating 297 scenarios in the long term.

\section{4.3. Simulation with catch crops over 60 years}

\section{4.3.1. $N$ sequestered in soil}

300 Figure 3 shows the evolution of $\mathrm{N}$ sequestered in soil due to catch crops since the beginning of the 301 experiments, simulated during 60 years in scenarios S3 to S6. It confirms the positive effect of catch 
302 crops on the long term: scenarios including catch crops allowed soil organic $\mathrm{N}$ to increase between 303430 and $750 \mathrm{~kg} \mathrm{~N}^{-1}$ in comparison with bare fallow soil (S1) depending on site and climate 304 series. The highest sequestration due to catch crops occurred at Kerlavic with ryegrass, while the 305 lowest was at Boigneville with mustard, $\mathrm{N}$ sequestration from radish at Thibie being intermediate. 306 Climate change resulted in slightly lower $\mathrm{N}$ sequestration at all sites (results not shown). When 307 catch crop frequency in the rotation was lowered from once every one or two years (S3) to once 308 every three or four years (S4), the $\mathrm{N}$ sequestered due to catch crops diminished by 292 to $388 \mathrm{~kg} \mathrm{~N}$ $309 \mathrm{ha}^{-1} \mathrm{yr}^{-1}$ (compared to scenario S3). In scenario S5, N fertilisation was adjusted (reduced by 20-24 $310 \mathrm{~kg} \mathrm{ha}^{-1} \mathrm{yr}^{-1}$ after the first 13-16 years) to account for the greater mineralization due to continuous 311 catch crops and maintain the crop yields at the same level than in the control scenario. This resulted 312 in a slight decrease of $\mathrm{N}$ stocks (-73 to $-132 \mathrm{~kg} \mathrm{ha}^{-1}$ ) compared with scenario S3, because crop 313 production and crop residues diminished. Abandoning catch crops (scenario S6) led to a progressive 314 decline in the extra $\mathrm{N}$ stored in the soil. The benefit of 13-16 years of repeated catch crops 315 disappeared progressively to reach zero after 60 years.

\subsubsection{Extra $N$ mineralization due to catch crops}

317 In parallel to change in $\mathrm{N}$ sequestration, continuous catch crops enhanced soil mineralization 318 compared with simulations without catch crops. After 60 years of continuous catch crops (S3), the 319 cumulative extra $\mathrm{N}$ mineralized reached 2950-3000 $\mathrm{kg} \mathrm{ha}^{-1}$ at Boigneville and Thibie and $1780 \mathrm{~kg}$ $320 \mathrm{ha}^{-1}$ at Kerlavic (Figure 4). Thus the mean amount of $\mathrm{N}$ mineralized annually due to catch crops 321 would represent 50 and $30 \mathrm{~kg} \mathrm{ha}^{-1} \mathrm{yr}^{-1}$ respectively. Adjusting fertilisation (S5) slightly decreased 322 extra mineralization by $9-16 \%$ compared to S3. Reducing the frequency of catch crops decreased it 323 much further, from 53\% to $68 \%$ according to site. Abandoning catch crops would induce a slow 324 return to the level of net mineralization simulated in the control treatment. $\mathrm{N}$ mineralization 325 remained higher during several years after catch cropping ceased, as long as organic $\mathrm{N}$ in soil 326 remained higher than in the control treatment. The extra mineralization $(\Delta M)$ of year $n$ can be 
327 compared to the input of $\mathrm{N}$ from catch crop residues $\left(N_{C C}\right)$ during year $n-1$; the ratio of these two

328 variables gives the relative mineralization rate: $M_{C C}=\Delta M / N_{C C}$ (Constantin et al., 2011). Figure 5

329 shows the evolution of $M_{C C}$ simulated during 60 years, without or with climate change (scenarios

330 S2 and S3 respectively). The model simulates annual fluctuations due to variability in climate and

331 catch crop production with regard to quantity and quality of residues. However, the general trend is

332 an asymptotic increase in extra $\mathrm{N}$ mineralization over time for both climate scenarios. The results

333 could be fitted to an exponential function, the asymptote of which was reached (within 10\%) in 23,

33426 and 45 years at Boigneville, Thibie and Kerlavic respectively, without climate change. The

335 asymptote was $M_{C C}=1.18,1.29$ and 1.14 corresponding to an extra mineralization of 58, 65 and 38

$336 \mathrm{~kg} \mathrm{ha}^{-1} \mathrm{yr}^{-1}$ respectively. These values were little affected by the climate change (scenario S3) which

337 resulted in a small decrease in the annual $\mathrm{N}$ input from catch crops only at Thibie $\left(-7 \mathrm{~kg} \mathrm{ha}^{-1} \mathrm{yr}^{-1}\right.$ on

338 average). The mean relative mineralization rate $\left(M_{C C}\right)$ over the 60 -year period was $1.01,1.02$ and

3390.74 at Boigneville, Thibie and Kerlavic, respectively. The lower annual extra mineralization

340 simulated at Kerlavic is mainly attributed to the type of catch crop residue with a higher C:N and

341 secondarily to the soil type.

\section{4.3.3. Nitrate leaching}

343 Figure 6 shows the cumulative reduction in nitrate leached due to catch crops over time, expressed

344 versus the cumulative amount of drained water. Over 60 years, the $\mathrm{N}$ saved from leaching with 345 continuous catch crops (scenario S3) represented 1209, 665 and $670 \mathrm{~kg} \mathrm{~N}^{-1}$ at Boigneville,

346 Thibie and Kerlavic respectively. Repeated catch crops resulted in a mean abatement of nitrate 347 concentration in drained water of 46,35 and $8 \mathrm{mg} \mathrm{NO}_{3}{ }^{-} \mathrm{L}^{-1}$ respectively. The kinetics were almost

348 linear during the first twenty years, indicating that catch crop efficiency in reducing nitrate leaching 349 was constant during these years. Later on, the kinetics became curvilinear, particularly at Kerlavic, 350 showing that catch crops became less and less efficient at preventing nitrate leaching. This change 351 was mainly due to the progressive increase in $\mathrm{N}$ mineralization rate which is harmful particularly 
352 during the long intercrop period (wheat-maize). An alternative to limit this effect (without changing 353 rotation) was to reduce $\mathrm{N}$ fertilisation rate, as proposed in scenario S5. Comparing scenarios S3 and 354 S5 shows that fertiliser adjustment was efficient in reducing $\mathrm{N}$ leaching on the long term. It was 355 able to save an extra 120, 102 and $299 \mathrm{~kg} \mathrm{~N}^{-1}$ over 60 years at Boigneville, Thibie and Kerlavic respectively. However, catch crop efficiency still decreased over time. A lower frequency of catch crop establishment in the rotation (scenario S4) also weakened its efficiency in reducing nitrate 358 leaching, since the reduction in $\mathrm{N}$ leached was only 476, 325 and $114 \mathrm{~kg} \mathrm{ha}^{-1}$ over the 60-year 359 period, and the corresponding nitrate abatement in drained water was 18,17 and $1 \mathrm{mg} \mathrm{L}^{-1}$ 360 respectively. After abandonment of catch crops, $\mathrm{N}$ leaching increased greatly and became greater 361 than without previous catch crop history during about the next 25 years. Over this period, the mean 362 amount of $\mathrm{N}$ leached was 4, 9 and $3 \mathrm{~kg} \mathrm{ha}^{-1} \mathrm{yr}^{-1}$ greater than in the control treatment (NoCC), with a 363 strong difference in the first years. This adverse effect on $\mathrm{N}$ leaching was due to higher 364 mineralization which resulted in higher $\mathrm{N}$ losses during winter. However, the establishment of catch 365 crops during 15 years had a global beneficial effect because they could save 251, 146 and $50 \mathrm{~kg} N$ $366 \mathrm{ha}^{-1}$ over the 60 years period at Boigneville, Thibie and Kerlavic respectively.

\section{5. Discussion}

\subsection{Performance of STICS model in continuous simulations}

370 The first step of this study consisted of evaluating the performance of the model in simulating crop 371 growth and uptake and environmental variables in three different pedo-climatic situations. After this

372 calibration stage which appeared necessary, the continuous simulations at the three sites over 15 373 years were satisfactory and as good as found in annual studies (e.g. Brisson et al., 2002; Jego et al., 374 2008). The simulated fertiliser $\mathrm{N}$ use efficiencies, which depend on fertiliser type, crop growth rate 375 and soil properties, were close to the mean measured values. The model simulated slightly negative 376 effects of catch crops on the $\mathrm{N}$ uptake of succeeding crops whereas the observed effects were nil or 
377 slightly positive (Table 7). Positive effect on biomass and N uptake have been reported by Hansen 378 and Djurhuus (1997). The absence of positive effects in the first years could be due to either a lack 379 of sensitivity of $\mathrm{N}$ uptake to $\mathrm{N}$ mineralization, or a lack of synchrony between extra mineralization 380 due to catch crops and crop $\mathrm{N}$ demand in the model. Since the residue decomposition model in 381 STICS has been successfully validated on decomposition of various catch crop residues in soil 382 (Justes et al., 2009), the first hypothesis seems the most appropriate. We also found that soil mineral 383 N was poorly simulated, although unbiased and better than reported by Houlès et al. (2004). In 384 contrast to another evaluation of STICS model (Sierra et al., 2003), soil water content at harvest 385 was not as well simulated, although it remained correct. In our study, drainage was overestimated by 10 to 20\%, as also reported by Schnebelen et al. (2004); however, we did not obtain a systematic overestimation of $\mathrm{N}$ leaching which was correctly simulated. The simulated effects of catch crops on leaching were well predicted in two sites out of three.

\section{2. $\mathbf{N}$ mineralization and storage in soil over 13-17 years}

390 The kinetics of net mineralization in situ was well simulated by the STICS model after calibration.

391 This result was obtained with standard parameterisation of soil mineralization at Thibie, while 392 modifications were needed on the two other sites to simulate well both mineralization and organic $393 \mathrm{~N}$ sequestration in soil. The dynamics of mineralization at Boigneville and Kerlavic were correctly 394 simulated by increasing the fraction of active organic matter in soil from $35 \%$ to $44 \%$ and $60 \%$ 395 respectively, indicating that this fraction could be dependent on soil characteristics, particularly on 396 previous land use history. According to models and authors, the active fraction can vary from 20397 40\% (Ludwig et al., 2003; Ludwig et al., 2007) to 90\% (ROTHC, Coleman and Jenkinson, 1996). 398 The large active fraction found at Kerlavic is attributed to the specific history of this site, with a 399 previous grassland. Extra N mineralization due to catch crops was well simulated by the model over 400 13-17 years after calibration. The hypotheses made about the importance of root biomass had a 401 significant impact on the simulated dynamics and its consistence with measured data. Indeed, we 
402 had to consider a large root biomass of ryegrass (larger than measured at harvest) in order to 403 correctly simulate N dynamics at Kerlavic (Constantin et al., 2011). Roots could represent an 404 important contribution to $\mathrm{C}$ and $\mathrm{N}$ storage in soil (e.g. Balesdent and Balabane, 1996). The 405 importance of this phenomenon has not received much attention in STICS model for two reasons: 406 the lack of experimental data and the fact that the model has mainly been used in annual 407 simulations. In summary, STICS model thus parameterized was able to simulate correctly and the 408 effects of catch crop on $\mathrm{N}$ mineralization and sequestration in the mid-term and could be used to 409 extrapolate to the longer term.

\subsection{Long-term effects of catch crops and steady state}

411 The model predicted that under constant rotation and repeated catch crops, the annual 412 mineralization increased progressively and then stabilised (within 10\%) after 23 to 45 years. The 413 former prediction was confirmed in two out three sites since significant cumulative effects were 414 observed at Thibie and Kerlavic during the first 15 years (Constantin et al., 2011). The annual extra 415 mineralization due to catch crops on year $n$ originate both from fresh catch crop residues (grown in 416 year $n$-1) and from stabilized organic matter formed earlier during decomposition of the previous 417 catch crop residues (grown in years 1 to $n$ ). The fresh residues contribute positively or negatively to 418 this annual rate depending on their C:N ratio (e.g. Whitmore and Groot, 1997; Trinsoutrot et al., 419 2000; Justes et al., 2009). The immobilisation of $\mathrm{N}$ due to the higher C:N ratio of ryegrass residues 420 explains the lower annual mineralization rate simulated over 60 years at Kerlavic (74\%) than at the 421 two other sites (>100\%). N immobilization occurs in soil during the first stages of decomposition, at 422 the expense of soil mineral $\mathrm{N}$. Therefore the total amount of $\mathrm{N}$ which becomes stabilized exceeds 423 the amount of $\mathrm{N}$ contained in the crop residues. This is why the relative rate of mineralization (Mcc) 424 can be greater than 1 as mentioned previously. These high annual rates highlight the necessity of 425 considering the previous catch crop history when evaluating the annual effect of catch crops. 


\section{4. $\mathrm{N}$ stock changes with continuous catch crops and effects of climate change}

427 The model also predicted that the $\mathrm{N}$ sequestered due to catch crops allowed maintaining the soil 428 organic matter level at steady state at two sites. At the third site (Kerlavic), repeated catch crops 429 limited but could not hamper the decline in SOM after grassland destruction. The range of decrease 430 at Kerlavic corresponded to the $30-50 \%$ decrease found after conversion of natural to agricultural 431 ecosystems over 50-100 years in temperate regions (Lal, 2008). The positive effect of catch crops 432 on $\mathrm{N}$ sequestration simulated by the model is in accordance with previous reports of positive effects 433 on N and C sequestration (Singh et al., 1998; Blombäck et al., 2003). In our simulations, climate 434 change led to a moderate increase in net $\mathrm{N}$ mineralization and reduction in soil organic $\mathrm{N}$, which 435 agrees with previous results for soil organic carbon (Hungate et al., 2009). In fact, the climate 436 change involves two opposing effects: an increase in mineralization rate and an increase in SOM 437 humification due to higher crop biomass and C return (Lal, 2008). The steady state obtained after 438 23-45 years with continuous catch crops was reached when the inputs in soil humified matter were 439 equal to the outputs, meaning that the annual input of humified $\mathrm{N}$ due to catch crops ( $\mathrm{N}$ of residues $440+\mathrm{N}$ immobilised from the soil) was equal to the extra annual mineralization. The steady state 441 occurred at a lower level when catch crop frequency declined due to smaller $\mathrm{N}$ inputs. When catch 442 crops were abandoned, the extra soil organic N progressively decreased to become negligible after 44360 years. This decline was also simulated by the FASSET model in Danish conditions when catch 444 crops were stopped after 30 years (Bernsten et al., 2006). It occurred at a slower rate: nearly $20 \%$ of 445 extra $\mathrm{N}$ sequestered remained in the soil 75 years after ceasing catch crops, while only 6-8\% 446 remained after 60 years in our simulations.

\section{5.5. Catch crop efficiency in decreasing leaching and fertilisation}

448 The reduction in nitrate leaching simulated by the model over the long-term confirmed that 449 fertilisation rate needs to be adjusted after a few years to maintain the efficiency of the catch crops 450 to reduce $\mathrm{N}$ leaching. The decrease in $\mathrm{N}$ fertilisation rate by $20-24 \mathrm{~kg} \mathrm{ha}^{-1} \mathrm{yr}^{-1}$ to maintain crop 
451 biomass production at the level of the control was similar to the reduction of $15-27$ and $23 \mathrm{~kg} \mathrm{ha}^{-1}$ $452 \mathrm{yr}^{-1}$ estimated in previous studies after 19 to 25 years of repeated catch crops (Hansen et al., 2000; 453 Berntsen et al., 2006). It allows compensating for the increase in net $\mathrm{N}$ mineralization with repeated 454 catch crops; when the annual mineralization rate reaches a steady state, the fertilisation rate does not 455 have to be reduced further. The decrease in catch crop efficiency for reducing nitrate concentration 456 in drained water can be expected at constant $\mathrm{N}$ fertilisation because of the enhanced mineralization 457 (Berntsen, 2006). The enhanced mineralization due to the extra organic $\mathrm{N}$ remaining in soil after 458 stopping catch crops resulted in greater amounts of $\mathrm{N}$ leached than in the control, confirming 459 previous findings (Thomsen and Christensen, 1999; Hansen et al., 2000). However, in our case this 460 phenomenon lasted much more than four years and nitrate leaching remained higher than in the 461 control during the whole simulation period, although with a progressive decrease. Overall catch 462 crops had a positive effect on $\mathrm{N}$ leaching over 60 years and their negative effects could be 463 minimised by adjusting the fertilisation rate to the higher mineralization, particularly during the first 464 years after stopping catch crops. In all cases, catch crops lead to slow down the nitrogen cascade 465 (Galloway et al., 2003). The 17-18\% N leaching reduction when catch crop frequency was 33-50\% 466 was slightly lower than the 23-28\% found in other studies (Olesen et al., 2004; Beaudoin et al., 467 2005). Our results indicate that, even with a low catch crop frequency, the fertilisation rate should 468 be decreased in the long term to maintain a good reduction in nitrate leaching. This is contradictory 469 with the hypothesis of MacDonald et al. (2005) that adjustments of fertiliser $\mathrm{N}$ recommendations 470 are not necessary in the case of small cover crops grown once every 3-4 years.

\section{6. Conclusions}

473 The crop-soil model STICS satisfactorily predicted crop and soil parameters in continuous 474 simulations over 15 years, confirming the robustness of the model which correctly reproduced the $\mathrm{N}$ 475 fate in three different pedo-climatic situations. A few parameters had to be calibrated because they 
Version définitive du manuscrit publié dans / Final version of the manuscript published in : Agriculture Ecosystems and Environment, 2011, In Press, DOI: 10.1016/j.agee.2011.06.

476 were not or could not be measured. Long-term simulations allowed us to determine the steady state 477 of net $\mathrm{N}$ mineralization and storage in soil due to repeated catch crops and confirmed the need to 478 adjust fertilisation rates when catch crops are grown repeatedly. The model simulated negative 479 effects of abandoning catch crops on $\mathrm{N}$ leaching, linked to changes in extra $\mathrm{N}$ in soil and extra 480 mineralization, years after catch cropping has ceased. The model outputs are logical with our 481 understanding of SOM turnover, although we cannot be sure of the intensity of the reduction in 482 catch crop efficiency with respect to nitrate leaching. The results presented here should be 483 compared with data from very long-term experiments to confirm these results. To obtain more 484 reliable simulations over the longer term, better data are needed on catch crop biomass, particularly 485 the root system, and the effects on nitrate leaching. Similarly, the active organic fraction should be 486 determined according to soil characteristics and previous land history. Long-term experiments and 487 simulation studies are complementary tools for defining sustainable agricultural practices.

\section{7. Acknowledgements}

489 This work was supported by ARVALIS Institut du Végétal, Région Picardie, Agence de l'Eau Seine-

490 Normandie and PIREN Seine. We are grateful to G.. Aubrion, F. Lancelot, A. Besnard, F. Lagadec, 491 C. Dominiarczyk, E. Venet, E. Burel and D. Boitez for their technical assistance and F. Huard for providing climatic scenarios with global warming. 


\section{References}

495 496

497 498

Aronsson, H., Tortensson, G., 1998. Measured and simulated availability and leaching of nitrogen associated with frequent use of catch crops. Soil Use Manag. 14, 6-13.

Balesdent, J., Balabane, M., 1996. Major contribution of roots to soil carbon storage inferred from maize cultivated soils. Soil Biol. Biochem. 28, 1261-1263.

Beaudoin, N., Saad, J., Van Laethem, C., Maucorps, J., Machet, J.M., Mary, B., 2005. Nitrate leaching in intensive arable agriculture in Northern France: effect of farming practices, soils and crop rotations. Agric. Ecosys. Environ. 111, 292-310.

Beaudoin, N., Launay, M., Sauboua, E., Ponsardin, G., Mary, B., 2008. Evaluation of the soil crop model STICS over 8 years against the “on farm” database of Bruyères catchment. Eur. J. Agr. 29, 46-57.

Berntsen, J., Olesen, J.E., Petersen, B.M., Hansen, E.M., 2006. Long-term fate of nitrogen uptake in catch crops. Eur. J. Agr. 25, 383-390.

Blombäck, K., Eckersten, H., Lewan, E., Aronsson, H., 2003. Simulations of soil carbon and nitrogen dynamics during seven years in a catch crop experiment. Agric. Syst. 76, 95-114.

Brisson, N., Mary, B., Ripoche, D., Jeuffroy, M.-H., Ruget, F., Gate, P., Devienne, F., Antonioletti, R., Dürr, C., Nicoullaud, B., Richard, G., Beaudoin, N., Recous, S., Tayot, X., Plenet, D., Cellier, P., Machet, J.M., Meynard, J.M., Delécolle, R., 1998. STICS: a generic model for the simulation of crops and their water and nitrogen balance. I- Theory and parameterization applied to wheat and corn. Agronomie 18, 311-346.

Brisson, N., Ruget, F., Gate, P., Lorgeou, J., Nicoullaud, B., Tayot, X., Plenet, D., Jeuffroy, M.H., Bouthier, A., Ripoche, D., Mary, B., Justes, E., 2002. STICS: a generic model for the simulation of crops and their water and nitrogen balances. II. Model validation for wheat and corn. Agronomie 22, 69-93.

Brisson, N., Gary, C., Justes, E., Roche, R., Mary, B., Ripoche, D., Zimmer, D., Sierra, J., Bertuzzi, P., Burger, P., Bussière, F., Cabidoche, Y.M., Cellier, P., Debaeke, P., Gaudillère, J.P., Hénault, C., Maraux, F., Seguin, B., Sinoquet, H., 2003. An overview of the crop model STICS. Eur. J. Agr. 18, 309-332. 
522 Brisson, N., Launay, M., Mary, B., Beaudoin, N., 2008. Conceptual basis, formalisations and 523 parameterisation of the STICS crop model. Editions QUAE, INRA, 78026 Versailles cedex.

524 Coleman, K., Jenkinson, D.S., 1996. RothC-26.3 - A model for the turnover of carbon in soil. In: 525 Powlson, D.S., Smith, P. \& Smith, J.U. (Eds.), Evaluation of soil organic matter models using 526 existing long-term datasets, Springer-Verlag Berlin, pp. 237-246.

527 Confalonieri, R., Acutis, M., Bellocchi, G., Donatelli, M., 2009. Multi-metric evaluation of the 528 models WARM, CropSyst, and WOFOST for rice. Ecol. Model. 220, 1395-1410.

529 Constantin, J., Mary, B., Laurent, F., Aubrion, G., Fontaine, A., Kerveillant, P., Beaudoin, N., 2010. 530 Effects of catch crops, no till and reduced nitrogen fertilization on nitrogen leaching and balance in 531 three long-term experiments. Agric. Ecosys. Environ. 135, 268-278.

532 Constantin, J., Beaudoin, N., Laurent, F., Duyme, F., Cohan, J.P., Mary, B., 2011. Cumulative 533 effects of catch crops on nitrogen uptake, leaching and net mineralization. Plant Soil 341, 137-154.

534 Déqué, M., 2007. Frequency of precipitation and temperature extremes over France in an 535 anthropogenic scenario: model results and statistical correction according to observed values. 536 Global Planet. Change 57, 16-26.

537 Gabrielle, B., Mary, B., Roche, R., Smith, P., Gosse, G.., 2002. Simulation of carbon and nitrogen 538 dynamics in arable soils: a comparison of approaches. Eur. J. Agr. 18, 107-120.

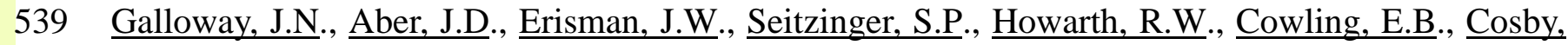
540 B.J., 2003. The nitrogen cascade. Bioscience 53, 341-356.

541 Giacomini, S.J., Recous, S., Mary, B., Aita, C., 2007. Simulating the effects of N availability, straw 542 particle size and location in soil on C and N mineralization. Plant Soil 301, 289-301.

543 Hansen, E.M., Djurhuus, J., 1997. Yield and N uptake as affected by soil tillage and catch crop. Soil 544 Till. Res. 42, 241-252.

545 Hansen, E.M., Kristensen, K., Djurhuus, J., 2000. Yield parameters as affected by introduction or 546 discontinuation of catch crop use. Agron. J. 92, 909-914.

547 Hénin, S., Gras, R., Monnier, G.., 1969. L’humidité du sol et sa mesure. In: Le profil cultural, 548 Masson et Cie, Paris, pp. 69-73. 
549 Houlès, V., Mary, B., Guérif, M., Makowski, D., Justes, E., 2004. Evaluation of the ability of the 550 crop model STICS to recommend nitrogen fertilisation rates according to agro-environmental 551 criteria. Agronomie 24, 339-349.

552 Hungate, B.A., van Groenigen, K.J., Six, J., Jastrow, J.D., Luo, Y., De Graaf, M.A., van Kessel, C., 553 Osenberg, C.W., 2009. Assessing the effect of elevated carbon dioxide on soil carbon: a comparison 554 of four meta-analyses. Global Change Biol. 15, 2020-2034.

555 Jego, G.., Martinez, I., Antiguedad, M., Launay, M., Sanchez-Perez, E., Justes, E., 2008. Evaluation 556 of the impact of various agricultural practices on nitrate leaching under the root zone of potato and 557 sugar beet using the STICS soil-crop model. Sci. Total Environ. 394, 207-221.

558 Justes, E., Mary, B., Nicolardot, B., 2009. Quantifying and modelling C and N mineralization 559 kinetics of catch crop residues in soil: parameterization of the residue decomposition module of 560 STICS model for mature and non mature residues. Plant Soil 325, 171-185.

561 Lal, R., 2008. Soil carbon stocks under present and future climate with specific reference to 562 European ecoregions. Nutr. Cycl. Agroecosys. 81, 113-127.

563 Lord, E.I., Shepherd, M.A., 1993. Developments in the use of porous ceramic cups for measuring 564 nitrate leaching. J. Soil Sci. 44, 435-449.

565 Ludwig, B., John, B., Ellerbrock, R., Kaiser, M., Flessa, H., 2003. Stabilization of carbon from 566 maize in a sandy soil in a long-term experiment. Eur. J. Soil Sci. 54, 117-126.

567 Ludwig, B., Schulz, E., Rethemeyer, J., Merbach, I., Flessa, H., 2007. Predictive modelling of C 568 dynamics in the long-term fertilization experiment at Bad Lauchstädt with the Rothamsted carbon 569 model. Eur. J. Soil Sci. 58, 1155-1163.

570 MacDonald, A.J., Poulton, P.R., Howe, M.T., Goulding, K.W.T., Powlson, D.S., 2005. The use of 571 cover crops in cereal-based cropping systems to control nitrate leaching in SE England. Plant Soil 572 273, 355-373.

573 Nash, J.E., Sutcliffe, J.V., 1970. River flow forecasting through conceptual models. Part I- A 574 discussion of principles. J. Hydrol. 10, 282-290.

575 Nicolardot, B., Recous, S., Mary, B., 2001. Simulation of C and N mineralization during crop 576 residue decomposition: a simple dynamic model based on the C:N ratio of the residues. Plant Soil 
Version définitive du manuscrit publié dans / Final version of the manuscript published in : Agriculture Ecosystems and Environment, 2011, In Press, DOI: 10.1016/j.agee.2011.06.

578 Olesen, J.E., Askegaard, M., Berntsen, J., 2004. Nitrate leaching from arable crop rotations in 579 organic farming. In: Hatch, D.J. et al. (Eds.), Controlling nitrogen flows and losses, Wageningen 580 Acad. Publishers, pp. 389-396.

581 Schnebelen, N., Nicoullaud, B., Bourennane, H., Couturier, A., Verbeque, B., Revalier, C., Bruand, 582 A., Ledoux, E., 2004. The STICS model to predict nitrate leaching following agricultural practices. 583 Agronomie 24, 423-435.

584 Schröder, J.J., VanDijk, W., DeGroot, W.J.M., 1996. Effects of cover crops on the nitrogen fluxes in 585 a silage maize production system. Neth. J. Agr. Sci. 44, 293-315.

586 Sierra, J., Brisson, N., Ripoche, D., Noël, C., 2003. Application of the STICS crop model to predict 587 nitrogen availability and nitrate transport in a tropical acid soil cropped with maize. Plant Soil 256, $588 \quad 333-345$.

589 Singh, B.R., Borresen, T., Uhlen, G., Ekeberg, E., 1998. Long-term effects of crop rotation, 590 cultivation practices and fertilizers on carbon sequestration in soils in Norway. In: Lal, R., Kimble, 591 J.M., Follett, R.F., Stewart, B.A. (Eds.), Management of carbon sequestration in soil, CRC Press, 592 Boca Raton, pp. 195-208.

593 Thomsen, I.K., Christensen, B.T., 1999. Nitrogen conserving potential of successive ryegrass catch 594 crops in continuous spring barley. Soil Use Manag. 15, 195-200.

595 Torstensson, G., Aronsson, H., 2000. Nitrogen leaching and crop availability in manured catch crop 596 systems in Sweden. Nutr. Cycl. Agroecosys. 56,139-152.

597 Trinsoutrot, I., Recous, S., Bentz, B., Lineres, M., Cheneby, D., Nicolardot, B., 2000. Biochemical 598 quality of crop residues and carbon and nitrogen mineralization kinetics under non limiting nitrogen 599 conditions. Soil Sci. Soc. Am. J. 64, 918-926.

600 Wallach, D., Buis, S., Lecharpentier, P., Bourges, J., Clastre, P., Launay, M., Bergez, J.-E., Guerif, 601 M., Soudais, J., Justes, E., 2011. A package of parameter estimation methods and implementation 602 for the STICS crop-soil model. Environ. Modell. Softw. 26, 386-394.

603 Webster, C.P., Shepherd, M.A., Goulding, K.W.T., Lord, E., 1993. Comparisons of methods for 604 measuring the leaching of mineral nitrogen from arable land. J. Soil Sci. 44, 49-62. 
Version définitive du manuscrit publié dans / Final version of the manuscript published in : Agriculture Ecosystems and Environment, 2011, In Press, DOI: 10.1016/j.agee.2011.06.

605 Whitmore, A.P., Groot, J.J.R., 1997. The decomposition of sugar beet residues: mineralization 606 versus immobilization in contrasting soil types. Plant Soil 192, 237-247.

607 Wösten, J.H.M., Pachepsky, Y.A., Rawls, W.J., 2001. Pedotransfer functions: bridging the gap 608 between available basic soil data and missing soil hydraulic characteristics. J. Hydrol. 251, 123-150. 


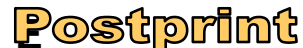

Version définitive du manuscrit publié dans / Final version of the manuscript published in : Agriculture Ecosystems and Environment, 2011, In Press, DOI: 10.1016/j.agee.2011.06.

\begin{tabular}{|c|c|c|c|}
\hline & Boigneville & Thibie & Kerlavic \\
\hline Rotation $^{\text {a }}$ & $\mathrm{SP} / \mathrm{b} / \mathrm{WW} / \mathrm{b} / \mathrm{SB} / \mathrm{b} /$ & $\begin{array}{l}\mathrm{SP} / \mathrm{b} / \mathrm{WW} / \mathrm{b} / \mathrm{S} / \mathrm{b} /(\text { until 2003) } \\
\mathrm{SB} / \mathrm{b} / \mathrm{S} / \mathrm{WW} / \mathrm{b} /(\text { after 2003) }\end{array}$ & $\mathrm{M} / \mathrm{WW} / \mathrm{b} /$ \\
\hline Fallow period $^{\mathrm{c}}$ & $\mathrm{CC}$ or $\mathrm{NoCC}$ & $\mathrm{CC}$ or $\mathrm{NoCC}$ & $\mathrm{CC}$ or $\mathrm{NoCC}$ \\
\hline $\begin{array}{l}\text { Catch crop: species, } \\
\text { frequency }\end{array}$ & $\begin{array}{l}\text { White mustard (Sinapis } \\
\text { alba), every year }\end{array}$ & $\begin{array}{c}\text { Radish (Raphanus satinus), } \\
\text { every year }^{\mathrm{d}}\end{array}$ & $\begin{array}{c}\text { Italian ryegrass ( Lolium } \\
\text { multiflorum), } 1 \text { year/2 }\end{array}$ \\
\hline Nitrogen treatment ${ }^{\mathrm{e}}$ & $\mathrm{N}$ & $\mathrm{N}$ or $\mathrm{N}-$ & $\mathrm{N}$ \\
\hline Form of $\mathrm{N}$ fertiliser & Solid ammonium nitrate & $\begin{array}{l}\text { Liquid urea ammonium- } \\
\text { nitrate }\end{array}$ & Solid ammonium nitrate \\
\hline Mean $\mathrm{N}$ rate $\left(\mathrm{kg} \mathrm{ha}^{-1} \mathrm{yr}^{-1}\right)$ & 103 & $85(\mathrm{~N}-)$ and $124(\mathrm{~N})$ & 125 \\
\hline Duration (years) & 16 & $13(\mathrm{~N}-)$ or $17(\mathrm{~N})$ & 13 \\
\hline
\end{tabular}

\footnotetext{
${ }^{a} \mathrm{WW}=$ winter wheat, $\mathrm{SB}=$ spring barley, $\mathrm{SP}=$ spring pea, $\mathrm{M}=$ silage maize, $\mathrm{S}=$ sugarbeet.

${ }^{\mathrm{b}}$ Fallow period with catch crops in the CC treatment.

${ }^{\mathrm{c}} \mathrm{CC}=$ with catch crop, No CC $=$ without catch crop.

d 2 years out of 3 after 2003 .

${ }^{\mathrm{e}} \mathrm{N}=$ recommended rate, $\mathrm{N}-=$ reduced rate $(69 \%$ of recommended rate).
}

Table 1: Main characteristics of the three mid term experiments. 
Version définitive du manuscrit publié dans / Final version of the manuscript published in : Agriculture Ecosystems and Environment, 2011, In Press, DOI: 10.1016/j.agee.2011.06.

\begin{tabular}{|c|c|c|c|c|c|c|c|}
\hline & & \multicolumn{2}{|c|}{ Boigneville } & \multicolumn{2}{|c|}{ Thibie } & \multicolumn{2}{|c|}{ Kerlavic } \\
\hline & & $0-30 \mathrm{~cm}$ & $30-90 \mathrm{~cm}$ & $0-30 \mathrm{~cm}$ & $30-110 \mathrm{~cm}$ & $0-30 \mathrm{~cm}$ & $30-90 \mathrm{~cm}$ \\
\hline Clay & $\mathrm{g} \mathrm{kg}^{-1}$ & 230 & & $90^{\mathrm{a}}$ & & 159 & \\
\hline Organic $\mathrm{N}^{\mathrm{b}}$ & $\mathrm{g} \mathrm{kg}^{-1}$ & 1.14 & & 1.51 & & 2.78 & \\
\hline Organic $\mathrm{C}^{\mathrm{b}}$ & $\mathrm{g} \mathrm{kg}^{-1}$ & 10.5 & & 14.2 & & 29.8 & \\
\hline $\mathrm{C}: \mathrm{N}$ ratio ${ }^{\mathrm{b}}$ & & 9.2 & & 9.4 & & 10.7 & \\
\hline $\mathrm{CaCO}_{3}$ & $\mathrm{~g} \mathrm{~kg}^{-1}$ & 20 & & 808 & & 0 & \\
\hline $\mathrm{pH}$ & & 7.0 & & 8.3 & & 5.8 & \\
\hline Bulk density ${ }^{b}$ & $\mathrm{~g} \mathrm{~cm}^{-3}$ & 1.42 & 1.50 & 1.40 & 1.50 & 1.26 & 1.43 \\
\hline $\mathrm{W}_{\mathrm{FC}}^{\mathrm{c}}$ & $\mathrm{g} \mathrm{kg}^{-1}$ & 251 & 243 & 269 & 240 & 332 & 271 \\
\hline $\mathrm{W}_{\mathrm{WP}}{ }^{\mathrm{c}}$ & $\mathrm{g} \mathrm{kg}^{-1}$ & 114 & 115 & 109 & 119 & 131 & 112 \\
\hline Albedo of bare soil ${ }^{\mathrm{d}}$ & & 0.16 & & 0.31 & & 0.15 & \\
\hline Mineralisation depth ${ }^{\mathrm{e}}$ & $\mathrm{cm}$ & 25.3 & & 26.4 & & 18.7 & \\
\hline
\end{tabular}

${ }^{\mathrm{a}}$ Measured after decarbonation.

${ }^{\mathrm{b}}$ Measured at harvest in 2007.

${ }^{\mathrm{c}}$ Water content at field capacity and permanent wilting point, respectively.

${ }^{\mathrm{d}}$ Estimated with soil texture as proposed by Brisson et al. (2008).

${ }^{\mathrm{e}}$ Equal to $110 \%$ of ploughing depth.

Table 2: Mean soil characteristics used in STICS model at each site. 


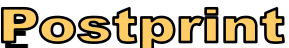

Version définitive du manuscrit publié dans / Final version of the manuscript published in : Agriculture Ecosystems and Environment, 2011, In Press, DOI: 10.1016/j.agee.2011.06.

\begin{tabular}{|c|c|c|c|c|c|}
\hline \multirow[b]{2}{*}{ Scenario } & \multicolumn{2}{|c|}{ Catch crop frequency (\%) } & \multicolumn{2}{|c|}{ Reduced $\mathrm{N}$ fertilisation } & \multirow{2}{*}{$\begin{array}{l}\text { Climate } \\
\text { change }\end{array}$} \\
\hline & $0-X$ years $^{\mathrm{a}}$ & X-60 years & 0 - $X$ years & X-60 years & \\
\hline $\mathrm{SO}^{\mathrm{b}}$ & 0 & 0 & No & No & No \\
\hline S1 & 0 & 0 & No & No & Yes \\
\hline $\mathrm{S} 2^{\mathrm{b}}$ & $100^{\mathrm{c}}$ & $100^{c}$ & No & No & No \\
\hline S3 & $100^{\mathrm{c}}$ & $100^{\mathrm{c}}$ & No & No & Yes \\
\hline S4 & $33^{d}$ & $33^{d}$ & No & No & Yes \\
\hline S5 & $100^{\mathrm{c}}$ & $100^{c}$ & No & Yes & Yes \\
\hline S6 & $100^{\mathrm{c}}$ & 0 & No & No & Yes \\
\hline
\end{tabular}

${ }^{\mathrm{a}} \mathrm{X}=16$ at Boigneville and 13 at Thibie and Kerlavic (duration of experimental period).

${ }^{\mathrm{b}}$ Scenario observed over 13-16 years.

c $50 \%$ at Kerlavic (once every two years).

d $25 \%$ at Kerlavic (once every four years).

Table 3: Scenarios tested over 60 years. 


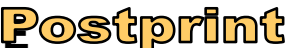

Version définitive du manuscrit publié dans / Final version of the manuscript published in : Agriculture Ecosystems and Environment, 2011, In Press, DOI: 10.1016/j.agee.2011.06.

\begin{tabular}{|c|c|c|c|c|c|c|c|c|}
\hline Crop & $\mathrm{n}$ & $\begin{array}{c}\text { Wheat } \\
132\end{array}$ & $\begin{array}{c}\text { Sugarbeet } \\
34\end{array}$ & $\begin{array}{c}\text { Pea } \\
9\end{array}$ & $\begin{array}{c}\text { Maize } \\
29\end{array}$ & $\begin{array}{c}\text { Barley } \\
48\end{array}$ & $\begin{array}{c}\text { Mustard } \\
39\end{array}$ & $\begin{array}{c}\text { Ryegrass } \\
34\end{array}$ \\
\hline SWC & MD & 18 & 3 & -19 & 2 & -3 & 2 & -2 \\
\hline \multirow[t]{2}{*}{$(\mathrm{mm})$} & RMSE & 51 & 35.4 & 29.0 & 29 & 47 & 19 & 22 \\
\hline & $E F$ & 0.58 & 0.93 & 0.87 & 0.91 & 0.82 & 0.85 & 0.84 \\
\hline & MD & 5 & -11 & 9 & -27 & -14 & -14 & -12 \\
\hline \multirow{2}{*}{$\left(\mathrm{kg} \mathrm{N} \mathrm{ha}^{-1}\right)$} & RMSE & 41 & 74 & 35 & 55 & 44 & 27 & 33 \\
\hline & $E F$ & 0.37 & 0.63 & 0.20 & 0.18 & 0.36 & 0.59 & 0.66 \\
\hline \multirow{3}{*}{$\begin{array}{l}\text { Aerial biomass } \\
\left(\mathrm{t} \mathrm{DM} \mathrm{ha}^{-1}\right)\end{array}$} & MD & 0.4 & -1.6 & -0.4 & -1.6 & -0.9 & -0.3 & 0.2 \\
\hline & RMSE & 2.1 & 3.6 & 1.1 & 2.9 & 2.7 & 0.8 & 1.2 \\
\hline & $E F$ & 0.90 & 0.85 & 0.94 & 0.83 & 0.70 & 0.88 & 0.34 \\
\hline \multirow{3}{*}{$\begin{array}{l}\text { Harvested biomass } \\
\left(\mathrm{t} \mathrm{DM} \mathrm{ha}{ }^{-1}\right)\end{array}$} & $\mathrm{MD}$ & -0.4 & 0.9 & -1.2 & & -1.6 & & \\
\hline & RMSE & 1.6 & 2.6 & 1.5 & ND & 2.2 & ND & ND \\
\hline & $E F$ & 0.57 & 0.85 & -3.5 & & -0.49 & & \\
\hline \multirow{3}{*}{$\begin{array}{l}\text { Aerial N uptake } \\
\left(\mathrm{kg} \mathrm{N} \mathrm{ha}^{-1}\right)\end{array}$} & $\mathrm{MD}$ & -2 & -15 & -17 & 1 & 10 & -17 & -8 \\
\hline & RMSE & 34 & 42 & 38 & 31 & 34 & 30 & 31 \\
\hline & $E F$ & 0.84 & 0.75 & 0.85 & 0.80 & 0.64 & 0.81 & 0.60 \\
\hline
\end{tabular}

Table 4: Performances of STICS model for various crops against the "reference" database 


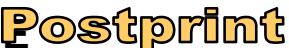

Version définitive du manuscrit publié dans / Final version of the manuscript published in : Agriculture Ecosystems and Environment, 2011, In Press, DOI: 10.1016/j.agee.2011.06.

\begin{tabular}{|c|c|c|c|c|c|c|c|}
\hline & \multicolumn{4}{|c|}{ Annual simulations } & \multicolumn{2}{|c|}{ Continuous simulations } \\
\hline & & $\begin{array}{l}\text { Maximal } \\
\text { rooting } \\
\text { depth } \\
(\mathrm{cm}) \\
\end{array}$ & $\begin{array}{c}\text { Lifespan of } \\
\text { winter wheat } \\
\text { leaves } \\
\text { (days) }\end{array}$ & $\begin{array}{c}\text { Lifespan of } \\
\text { catch crop } \\
\text { leaves } \\
\text { (days) }\end{array}$ & $\begin{array}{c}\text { Potential of } \\
\text { fertilizer N } \\
\text { loss }^{\text {a }} \\
(\%) \\
\end{array}$ & $\begin{array}{c}\text { Active } \\
\text { SOM } \\
\text { fraction } \\
(\%) \\
\end{array}$ & $\begin{array}{c}\text { Initial } \\
\text { organic N } \\
\text { content } \\
\left(\mathrm{g} \mathrm{kg}^{-1}\right) \\
\end{array}$ \\
\hline \multirow[t]{2}{*}{ Boigneville } & Initial & 90 & 200 & 150 & $15 \%$ & 0.35 & $1.14^{\mathrm{b}}$ \\
\hline & Fitted & 70 & 100 & 90 & $15 \%$ & 0.44 & 1.21 \\
\hline \multirow[t]{2}{*}{ Thibie } & Initial & 90 & 200 & 150 & $15 \%$ & 0.35 & $1.51^{\mathrm{b}}$ \\
\hline & Fitted & 85 & 100 & 100 & $15 \%$ & 0.35 & 1.52 \\
\hline \multirow[t]{2}{*}{ Kerlavic } & Initial & 90 & 200 & 140 & $15 \%$ & 0.35 & $2.78^{\mathrm{b}}$ \\
\hline & Fitted & 60 & 100 & 80 & $35 \%$ & 0.60 & 3.20 \\
\hline
\end{tabular}

${ }^{\text {a }}$ Due to denitrification (\% of fertilizer-N added)

${ }^{\mathrm{b}}$ Measured in 2007

Table 5: Model parameter values before ('initial') and after model calibration ('fitted'). The calibration was applied to half the "catch crop" database and the validation was made on the other half, for each site. 
Version définitive du manuscrit publié dans / Final version of the manuscript published in : Agriculture Ecosystems and Environment, 2011, In Press, DOI: 10.1016/j.agee.2011.06.

\begin{tabular}{|c|c|c|c|c|c|c|c|}
\hline & \multicolumn{3}{|c|}{ Calibration dataset } & \multicolumn{3}{|c|}{ Validation dataset } \\
\hline & & Boigneville & Thibie & Kerlavic & Boigneville & Thibie & Kerlavic \\
\hline \multicolumn{2}{|c|}{ Number of observations } & 15 & 84 & 24 & 15 & 84 & 24 \\
\hline \multirow{4}{*}{$\begin{array}{l}\text { SWC at harvest } \\
(\mathrm{mm})\end{array}$} & $\mathrm{M}^{\mathrm{a}}$ & 217 & 220 & 233 & 221 & 217 & 221 \\
\hline & $\mathrm{MD}^{\mathrm{b}}$ & 3 & 2 & 23 & -1 & 10 & 35 \\
\hline & $\mathrm{RMSE}^{\mathrm{c}}$ & 27 & 39 & 42 & 23 & 39 & 51 \\
\hline & $\mathrm{EF}^{\mathrm{d}}$ & 0.11 & 0.26 & 0.38 & 0.43 & 0.23 & 0.01 \\
\hline \multirow{4}{*}{$\begin{array}{l}\text { SMN at harvest } \\
\left(\mathrm{kg} \mathrm{N} \mathrm{ha}^{-1}\right)\end{array}$} & $\mathrm{M}$ & 44 & 44 & 36 & 42 & 39 & 43 \\
\hline & MD & 15 & 2 & 6 & 6 & 10 & 6 \\
\hline & RMSE & 25 & 29 & 14 & 26 & 29 & 17 \\
\hline & $\mathrm{EF}$ & -1.95 & -0.93 & -0.48 & -2.00 & -1.06 & -0.28 \\
\hline \multirow{4}{*}{$\begin{array}{l}\text { Aerial biomass } \\
\left(\mathrm{t} \mathrm{DM} \mathrm{ha}^{-1}\right)\end{array}$} & $\mathrm{M}$ & 8.1 & 10.4 & 10.2 & 9.0 & 9.4 & 10.1 \\
\hline & MD & 0.7 & 0.4 & 2.2 & 0.2 & 0.6 & 2.2 \\
\hline & RMSE & 1.8 & 4.3 & 3.9 & 1.7 & 4.3 & 3.8 \\
\hline & $\mathrm{EF}$ & 0.90 & 0.72 & 0.18 & 0.92 & 0.72 & 0.24 \\
\hline \multirow{4}{*}{$\begin{array}{l}\text { Harvested biomass } \\
\left(\mathrm{t} \mathrm{DM} \mathrm{ha}^{-1}\right)\end{array}$} & M & 6.3 & 9.4 & - & 6.5 & 9.8 & - \\
\hline & MD & -0.5 & 0.2 & - & -0.9 & -0.3 & - \\
\hline & RMSE & 1.2 & 2.9 & - & 1.6 & 2.8 & - \\
\hline & EF & 0.53 & 0.73 & - & 0.20 & 0.76 & - \\
\hline \multirow{4}{*}{$\begin{array}{l}\text { Aerial } \mathrm{N} \text { uptake } \\
\left(\mathrm{kg} \mathrm{N} \mathrm{ha}^{-1}\right)\end{array}$} & $\mathrm{M}$ & 142 & 161 & 156 & 155 & 152 & 153 \\
\hline & MD & 4 & -8 & 12 & -2 & -7 & 11 \\
\hline & RMSE & 26 & 51 & 36 & 24 & 48 & 37 \\
\hline & $\mathrm{EF}$ & 0.90 & 0.68 & 0.41 & 0.89 & 0.75 & 0.53 \\
\hline \multirow{4}{*}{$\begin{array}{l}\text { Harvested N } \\
\left(\mathrm{kg} \mathrm{N} \mathrm{ha}^{-1}\right)\end{array}$} & $\mathrm{M}$ & 147 & 125 & - & 149 & 128 & - \\
\hline & $\mathrm{MD}$ & -16 & 4 & - & -26 & -4 & - \\
\hline & RMSE & 28 & 31 & - & 36 & 29 & - \\
\hline & $\mathrm{EF}$ & 0.41 & 0.06 & - & 0.13 & 0.22 & - \\
\hline \multirow{4}{*}{$\begin{array}{l}\text { Drained water } \\
(\mathrm{mm})\end{array}$} & $\mathrm{M}$ & 152 & 130 & 593 & 148 & 107 & 563 \\
\hline & MD & 33 & 13 & 67 & 30 & 23 & 88 \\
\hline & RMSE & 57 & 53 & 160 & 67 & 54 & 181 \\
\hline & $\mathrm{EF}$ & 0.49 & 0.66 & 0.58 & 0.38 & 0.57 & 0.44 \\
\hline \multirow{4}{*}{$\begin{array}{l}\text { Leached N } \\
\left(\mathrm{kg} \mathrm{N} \mathrm{ha}^{-1}\right)\end{array}$} & $\mathrm{M}$ & 25 & 22 & 55 & 23 & 19 & 55 \\
\hline & MD & 4 & -3 & 7 & 9 & -2 & 6 \\
\hline & RMSE & 18 & 18 & 26 & 21 & 14 & 29 \\
\hline & $\mathrm{EF}$ & -0.34 & 0.41 & 0.44 & -0.36 & 0.54 & 0.18 \\
\hline
\end{tabular}

\footnotetext{
${ }^{\mathrm{a}} \mathrm{M}=$ mean observed value.

${ }^{\mathrm{b}} \mathrm{MD}=$ mean deviation

${ }^{\mathrm{c}} \mathrm{RMSE}=$ root mean square error

${ }^{\mathrm{d}} \mathrm{EF}=$ model efficiency
}

Table 6: Model evaluation against the "catch crop" database using continuous simulations: mean observed value and statistical criteria for soil water content (SWC), mineral N content (SMN), crop production at harvest, drained water and leached $\mathrm{N}$. 


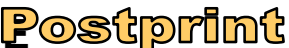

Version définitive du manuscrit publié dans / Final version of the manuscript published in : Agriculture Ecosystems and Environment, 2011, In Press, DOI: 10.1016/j.agee.2011.06.

\begin{tabular}{|c|c|c|c|c|c|c|}
\hline & Effect* & Site & $\begin{array}{r}\text { Observed } \\
\mathrm{kg} \mathrm{ha}\end{array}$ & $\begin{array}{l}\text { Simulated } \\
{ }^{-1} \mathrm{yr}^{-1}\end{array}$ & $\begin{array}{c}\text { Correlation } \\
\text { coefficient }\end{array}$ & $\begin{array}{c}\text { Model } \\
\text { efficiency }\end{array}$ \\
\hline \multirow[t]{4}{*}{$\Delta \mathrm{N}$ uptake } & S2-S0 & Boigneville & 0 & -8 & $0.91(n s)$ & 0.67 \\
\hline & S2-S0 & Thibie & 4 & -7 & & \\
\hline & S2-S0 & Kerlavic & 4 & 3 & & \\
\hline & $\mathrm{N}^{-}-\mathrm{N}$ & Thibie & -24 & -21 & & \\
\hline \multirow[t]{4}{*}{$\Delta \mathrm{N}$ leached } & S2-S0 & Boigneville & -11 & -25 & 0.80 (ns) & 0.55 \\
\hline & S2-S0 & Thibie & -18 & -18 & & \\
\hline & S2-S0 & Kerlavic & -32 & -28 & & \\
\hline & $\mathrm{N}^{-}-\mathrm{N}$ & Thibie & -3 & -1 & & \\
\hline
\end{tabular}

* S2-S0 = catch crop effect

$\mathrm{N}^{-}-\mathrm{N}=$ reduced fertilisation effect.

Table 7: Observed and simulated extra $\mathrm{N}$ uptake and extra $\mathrm{N}$ leached due to catch crops (S2) and reduced fertilisation $\left(\mathrm{N}^{-}\right)$, compared with conventional practices $(\mathrm{S} 0$ and $\mathrm{N})$ in continuous simulations. 
Version définitive du manuscrit publié dans / Final version of the manuscript published in : Agriculture Ecosystems and Environment, 2011, In Press, DOI: 10.1016/j.agee.2011.06.

Figure 1 Observed and simulated water contents in the soil profile (SWC) a) at several dates per year in the "reference" database and b) at harvest of the main crops in the "catch crop" database.
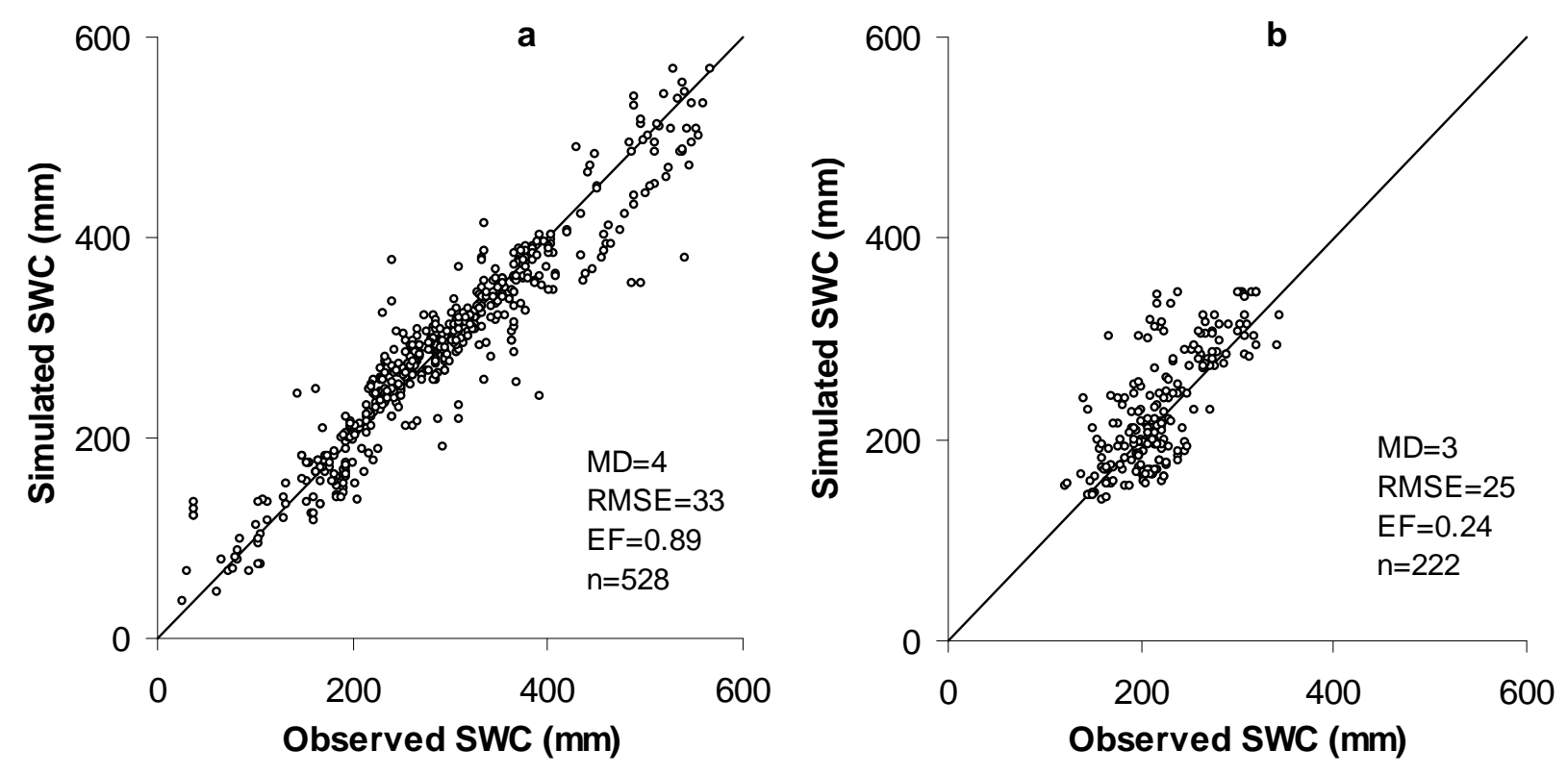
Figure 2 Observed and simulated kinetics of cumulative net $\mathrm{N}$ mineralization at Boigneville (a), Thibie (b) and Kerlavic (c), for scenarios S0 and S2 over 13-17 years in continuous simulations.
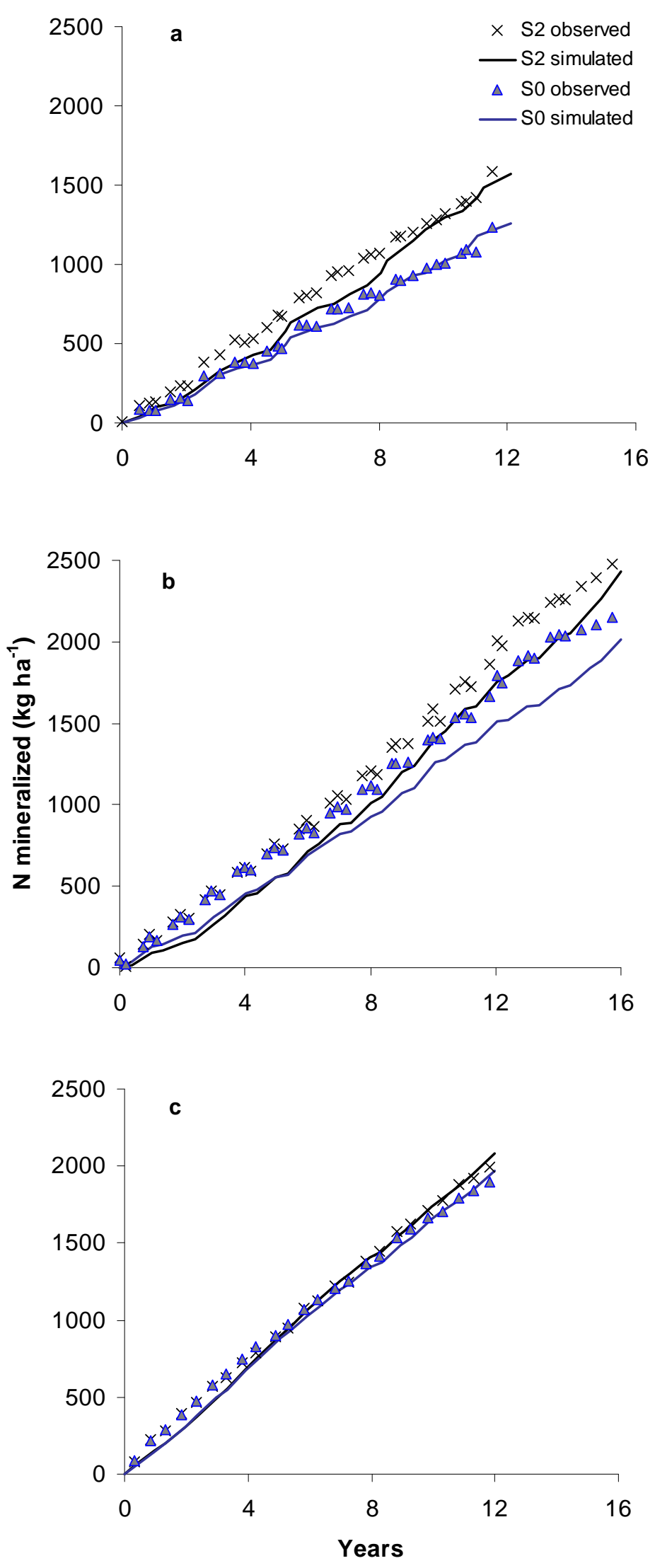
Figure 3 Kinetics of organic $\mathrm{N}$ sequestered in soil ( $\Delta \mathrm{N}$ stock) due to catch crops, simulated with four scenarios (continuous lines) at Boigneville (a), Thibie (b) and Kerlavic (c). The symbols represent the mean and confidence interval of the measured $\Delta \mathrm{N}$ stock after 13-17 years (corresponding to scenario S3).
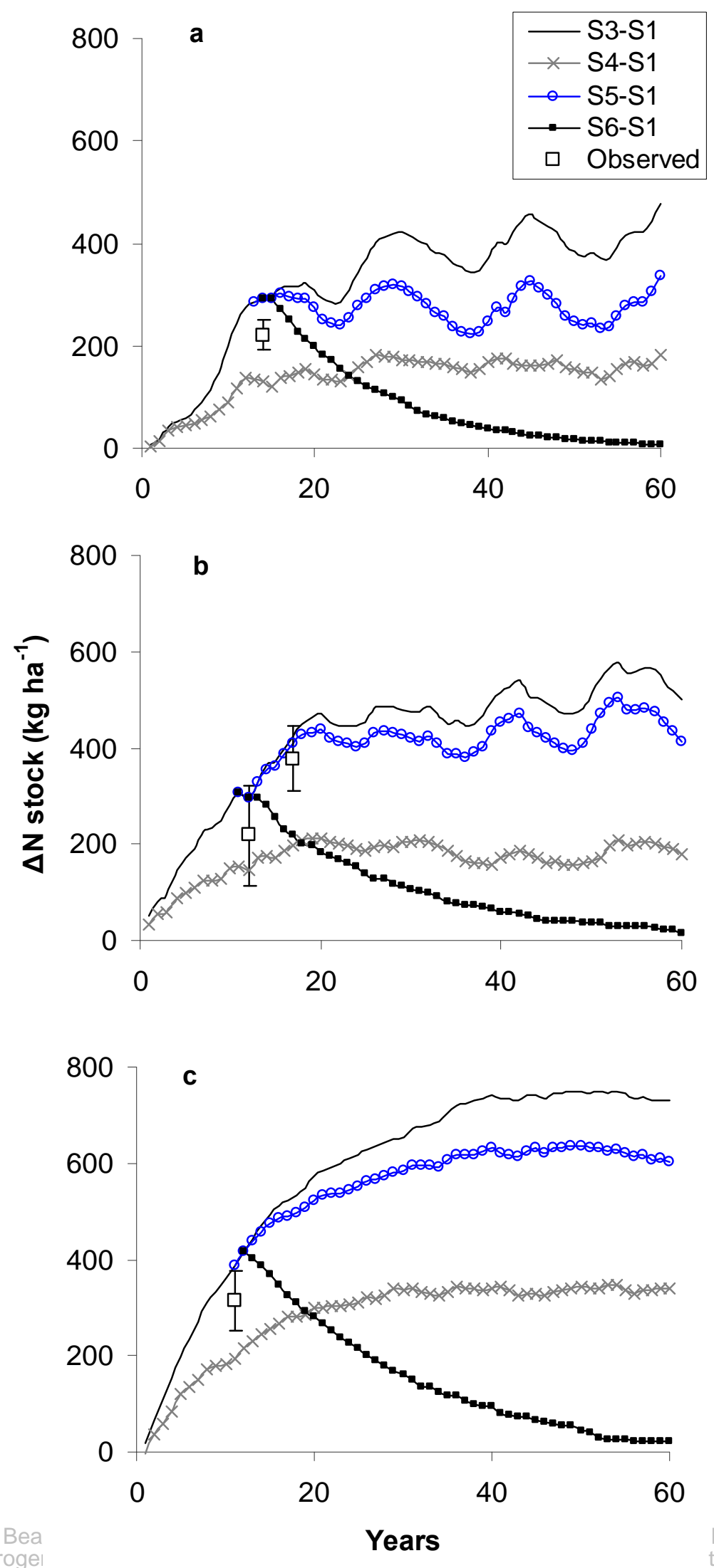
Figure 4 Kinetics of extra $\mathrm{N}$ mineralization (cumulative) due to catch crops, simulated with the four scenarios (continuous lines) at Boigneville (a), Thibie (b) and Kerlavic (c). The symbols represent the "observed" values which were calculated using a $\mathrm{N}$ mass balance (see text) and correspond to scenario S3.
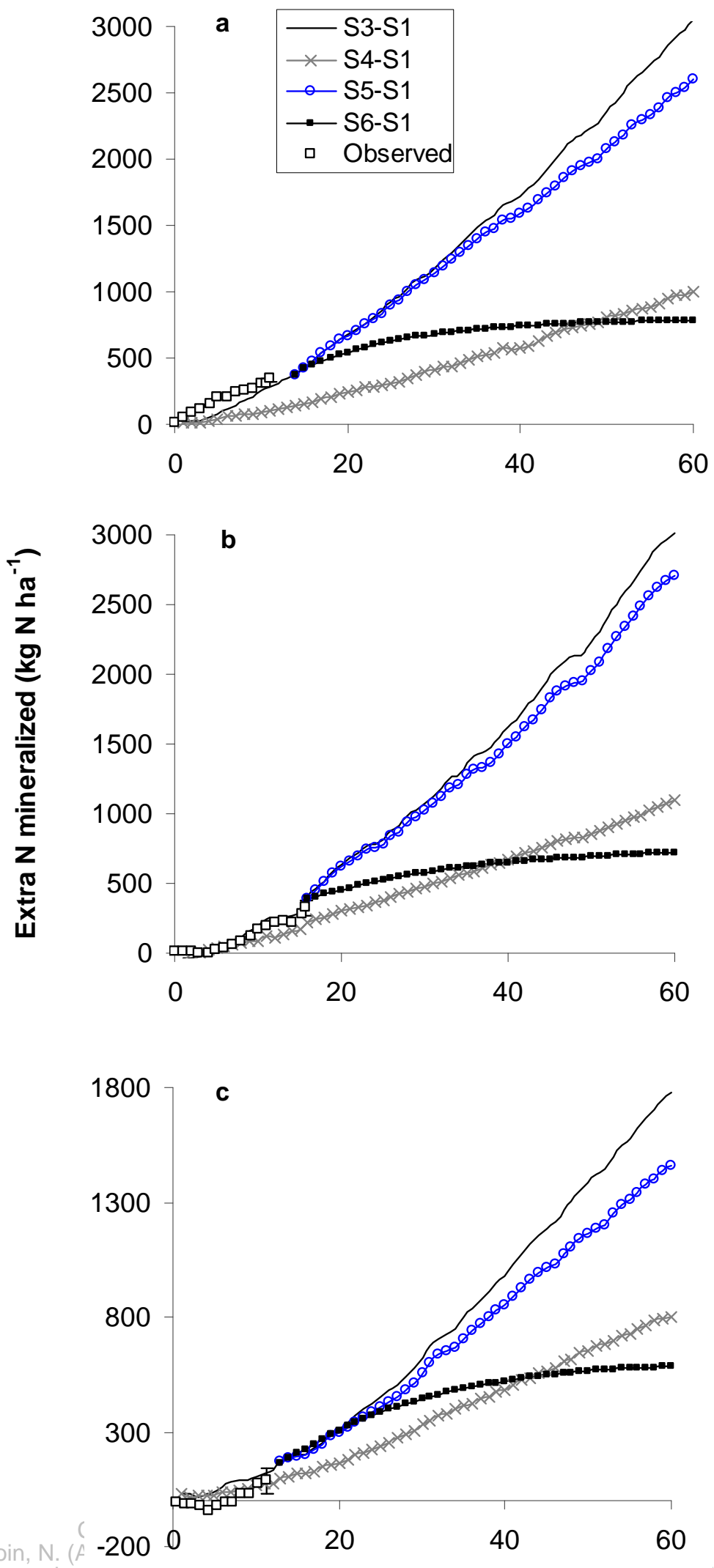
Figure 5 Evolution of the annual relative mineralization rate $\left(M_{C C}\right)$ due to catch crops simulated over 60 years in scenarios S2 and S3 at Boigneville (a), Thibie (b) and Kerlavic (c). $M_{C C}$ is the ratio between the extra $\mathrm{N}$ mineralized due to catch crops during year $n$ and the $\mathrm{N}$ added to soil by catch crops during year $n-1$. Symbols are the values simulated by STICS; continuous lines are the fitted curves (exponential).
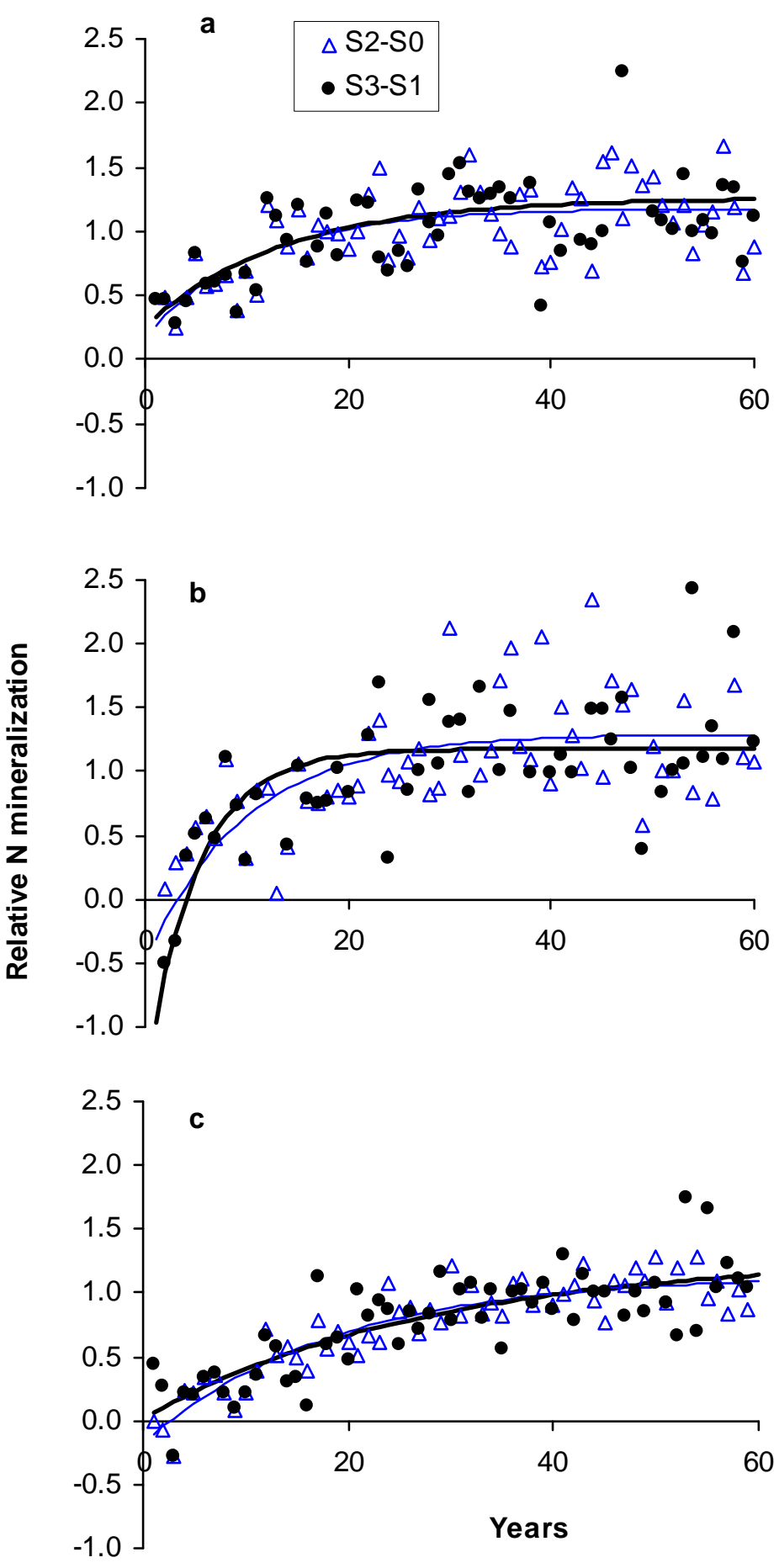
Figure 6 Cumulative extra $\mathrm{N}$ leached due to catch crops versus cumulative drained water, simulated over 60 years in scenarios S3-S6 at Boigneville (a), Thibie (b) and Kerlavic (c). The symbols represent the mean and confidence interval of the measured extra $\mathrm{N}$ leached (corresponding to scenario S3).

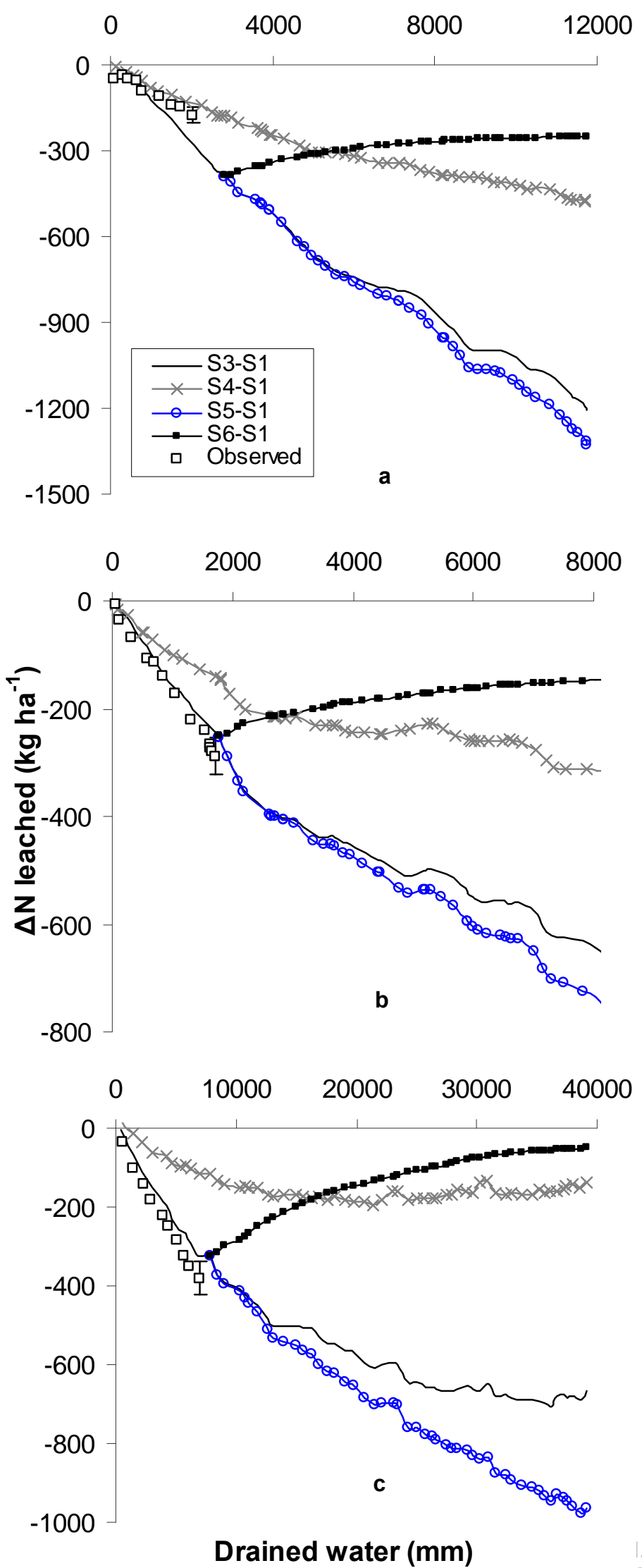

